\title{
Chemical composition and antimicrobial activity of Pinus halepensis from Algeria
}

\author{
RIMA HAICHOUR ${ }^{1,2}$, MESSAOUD RAMDANI ${ }^{1, \vartheta}$, TAKIA LOGRADA $^{1}$, PIERRE CHALARD ${ }^{3}$, \\ GILLES FIGUEREDO ${ }^{4}$ \\ ${ }^{1}$ Laboratory of Natural Resource Valorisation, Faculty of Life and Natural Sciences, Ferhat Abbas University Setif-1. 19000 Setif, Algeria \\ Tel./fax.: +213-658-101010, `email: ramdanimessaoud@yahoo.com \\ ${ }^{2}$ Department of Natural Sciences, Mohamed Boudiaf University of M'sila. PB 166 M'sila 28000, Algeria \\ ${ }^{3}$ Université Clermont Auvergne, CNRS, SIGMA Clermont, ICCF, F-63000 Clermont-Ferrand, France \\ ${ }^{4}$ LEXVA Analytique, 460 Rue Du Montant, 63110 Beaumont, France
}

Manuscript received: 29 July 2020. Revision accepted: 27 August 2020.

\begin{abstract}
Haichour R, Lograda T, Ramdani M, Chalard P, Figueredo G. 2020. Chemical composition and antimicrobial activity of Pinus halepensis from Algeria. Biodiversitas 21: 4345-4360. The chemical composition of Pinus halepensis essential oils and their antibacterial activities were investigated. Plant samples were collected in the flowering stage from the East locality of Algeria. The aerial parts of $P$. halepensis from fifteen localities were subjected to a hydro-distillation. The analysis of the chemical composition of essential oils was performed by using GC, and GC / MS. Hydro-distillation of $P$. halepensis produces a pale yellow viscous oil with an average yield of $0.64 \pm 0.37 \%$. A total of thirty-seven compounds representing $99.4 \pm 0.5 \%$ of the total oils were identified in $P$. halepensis. The hydrocarbon compounds were found to dominate essential oils in $P$. halepensis. In addition, the major compounds were caryophyllene-E $(29.06 \pm 8.5 \%)$, myrcene $(19.14 \pm 6.67 \%)$, $\alpha$-pinene $(16.86 \pm 3.35 \%)$, phenyl ethyl 3-methyl butanoate $(5.67 \pm 2.47 \%)$, $\alpha$-humulene $(4.81 \pm 1.43 \%)$, terpinolene $(3.94 \pm 1.6 \%)$ and sabinene $(3.11 \pm 1.84 \%)$. The essential oil samples were clustered in five groups based on their chemical composition by UPGMA analysis. The first group includes the Tafrent essential oil population. It is characterized by the phenyl ethyl-3-methyl butanoate - Sabinene $-\Delta 3$-carene chemotype. The second group was subdivided into two clusters. The $1^{\text {st }}$ cluster or chemotype was characterized by the myrcene $-\alpha$-pinene - caryophyllene-E. The second chemotype was characterized by caryophyllene- E - $\alpha$-humulene - myrcene. The essential oil of $P$. halepensis is an effective antimicrobial against Staphylococcus aureus; Klebsiella pneumonia; Salmonella enteric spp arizonae; Listeria innocua; Proteus mirabilis and Bacillus cereus, and not active against E. coli and Pseudomonas aeruginosa.
\end{abstract}

Keywords. Algeria, antibacterial activity, bioactive molecules, chemotypes, essential oil, Pinus halepensis

\section{INTRODUCTION}

Pinus halepensis is a plant species widely distributed around the Mediterranean and over the mountain massifs (Correal-Mòdol and Casals 2012). In Algeria, it is found in all bioclimatic variants, especially in the semi-arid stage, showing high dominance (Quezel and Barbero 1992). Pines are characterized by high levels of fatty acids, vitamin E, polyphenols and natural antioxidants, widely used for cosmetics (Ustun et al. 2006) and the food industry (Chikh Rouhou 2006; Kadri et al. 2014). Aleppo pine resin is commonly used in popular medicine, as a powerful antiseptic, and as a cure for treating infections of respiratory and urinary tracts, gallstones, sinusitis, and rheumatism (Motte-Florac 2000; Berroukche et al. 2014). The chemical composition of $P$. halepensis essential oils has been widely studied (Roussi et al. 1995; Hmamouchi et al. 2001; Lahlou 2003; Macchioni et al. 2003; Dob et al. 2005; Dob et al. 2007; Tumen et al. 2010; Abi-Ayad et al. 2011; Ustun et al. 2012, Gallis et al. 2012; Amri et al. 2013; Amri et al. 2014; Efestathia et al. 2014; Djerrad et al. 2015; Fekih et al. 2015; Mohareb et al. 2017; El Baha et al. 2016; Nam et al. 2016; Rodrigues et al. 2017; Bouyahiya et al. 2019; Mitić et al. 2019) (Table S1).
The essential oils possess bioactive properties due to the mixture of various volatile compounds, including monoterpenes as the main component, which makes an important contribution to pathogen resistance (Sharma et al. 2019). A previous study on the chemical composition of Tunisian Aleppo pine essential oils showed the presence of $\beta$-elemene, $\alpha$-humulene, $\alpha$-pinene, and $\beta$-pinene (Dziri and Hosni 2012). Populations from other places are mainly composed of $\beta$-caryophyllene-E, myrcene, and $\alpha$-pinene (Amri et al. 2014). The essential oil of Aleppo pine populations from Morocco and Italy contains $\alpha$-pinene, myrcene, and $\beta$ caryophyllene-E (Hmamouchi et al. 2001; Macchioni et al. 2003). The population from Italy contained $\beta$-caryophylleneE, myrcene, $\rho$-cymene, and $\alpha$-pinene (Vidrich et al. 1988). The essential oil of Aleppo pine from Greece was rich in $\beta$ caryophyllene-E, $\alpha$-pinene, and cembrene (Roussis et al. 1995; Gallis et al. 2012). Corsica population is characterized by $\beta$-caryophyllene-E, myrcene, $\alpha$-pinene, terpinolene, $\Delta 3$ carene, and sabinene (Nam et al. 2016). P. halepensis essential oils populations of Turkey exhibited the presence of $\alpha$-pinene and $\beta$-pinene (Ustun et al. 2012). The main chemical composition of $P$. halepensis varies widely in different countries, with different various main components. The main compounds of Aleppo pine in Portugal are $\alpha$ - 
pinene, $\beta$-myrcene, $\Delta 3$-carene, and $\beta$-caryophyllene (Rodriguez et al. 2017). The main compounds of Aleppo pine in Libya are $\alpha$-pinene, $\beta$-pinene, $\alpha$-terpineol, and caryophyllene (Mohareb et al. 2016). Besides, the main compounds of Aleppo pine from Egypt and caryophyllene, $\alpha$-pinene, and thumbergol (El-Baha et al. 2016). The essential oil of Aleppo pine from three different altitudes in Libya are a high percentage of $\alpha$-pinene, $\beta$-pinene, $\alpha$ terpineol, and caryophyllene (Mohareb et al. 2016). The Greece populations are abundant in $\beta$-Caryophyllene-E and thumberguol (Mitić et al. 2019). The chemical composition of $P$. halepensis essential oils from various locations in Algeria have been well documented (Table S2).

The chemical composition of essential oils from populations in some regions in Algeria (Sidi Feradj, Djelfa, and Saïda) showed that the main compounds are $\beta$ caryophyllene- $Z$, $\alpha$-humulene, aromadendrene (Dob et al. 2007). The essential oil of the Ghazaouet population contains mainly caryophyllene oxide (48.1\%) and $\beta$-caryophylleneE (2.9\%) (Abi-Ayad et al. 2011). The Tlemcen populations consist of two groups; one is characterized by myrcene, $\alpha$ pinene, terpinolene, and isovalerate-2-phenylethyl, and the other one is dominated by myrcene, $\alpha$-pinene and $\beta$-caryophyllene-E (Fekih et al. 2014). Aleppo pine was found to be rich in $\alpha$-pinene, myrcene, terpinolene, and terpinene-4ol in the Tebessa region (Djerrad et al. 2015), while the essential oils of Tissemsilt populations contain myrcene, iso-valerate of 2-phenylethyl and $\beta$-caryophyllene-E as the main compounds (Tazerouti et al. 1993). The Aleppo Pine essential oils contain various bioactive compounds, that have, antioxidant (Ustum et al. 2012; Djerrad et al. 2015; Tumen et al. 2018), antibacterial (Fekih et al. 2014; Ghalem et al. 2014), antifungals (El Baha et al. 2016), antiinflammatories (Suntar et al. 2012) and anticancer (Simard 2007; Alonso-Castro et al. 2011; Kadri et al. 2014; Bouzenna et al. 2016), activities.

Several previous studies have investigated the antibacterial activities of $P$. halepensis essential oils. The studies showed that Aleppo pine essential oil is active as an antibacterial against E. coli, B. subtilis, Micrococcus luteus, and Staphylococcus aureus (Ghanmi et al. 2007; Raho et al. 2014; Fekih et al. 2014; Ashmawy et al. 2018). The previous studies showed that several bacteria are sensitive to the essential oil of P.halepensis, i.e., Agrobacterium tumefaciens, Erwinia carotovora, Corynebacterium fascians, Pseudomonas solanacearum (Mohareb et al. 2016), Klebsiella pneumoniae, E. coli, Morganella morganii, Staphylococcus aureus (Mitić et al. 2019), E. coli, Staphylococcus aureus, Listeria monocytogenes (Bouyahya et al. 2019), and P. aeruginosa (Abi-Ayad et al. 2011).

The present study aimed to determine the chemical composition of the essential oils of Pinus halepensis from the east locality of Algeria, to identify the different possible chemotypes from the studied populations, and to evaluate their antibacterial activity against eight bacterial strains.

\section{MATERIALS AND METHODS}

\section{Plant materials}

Aerial parts of Pinus halepensis were collected when they were in flowering in November 2016. There were five sampling sites in northern Algeria, Boutaleb (south of Setif city), Babor (north of Setif), Ouled Yaakoub forest (Khanechela city), Seriana forest (Batna city) and Jijel (Figure 1).

The geographical coordinates of sampling sites were presented in Table 1. Voucher specimens were deposited in the Herbarium of Biology and Ecology Department, Setif-1 University, Algeria.

\section{Hydro-distillation of aerial part of Pinus halepensis}

Hydrodistillation of air-dried materials using a Clevenger apparatus type was carried out for 3 hours. The obtained essential oil was dried with sodium sulfate anhydrous. The yield was calculated based on the dry weight of samples.

\section{Essential oil analysis}

Chemical composition of essential oils was analyzed by Gas Chromatography (Hewlett-Packard CPG/FID 7890) coupled to Gas Chromatograph apparatus (CPG/MS 7890/5975C). It is equipped with a column A polar (DB5 MS: $40 \mathrm{~m} 0.18 \mathrm{~mm} 0.18 \mu \mathrm{m})$, programming from $50^{\circ} \mathrm{C}$ for $(5$ min) to $5^{\circ} \mathrm{C} / \mathrm{min}$, until $300^{\circ} \mathrm{C}$. Helium was used as the carrier gas $(1.0 \mathrm{~mL} / \mathrm{min})$, injector in split mode $(1: 30)$, and injector and detector temperature of $280^{\circ} \mathrm{C}$ with $1 / 100$ split. The mass spectrometer worked in EI mode at $70 \mathrm{eV}$; electron multiplier, $2500 \mathrm{~V}$; Ion source temperature of $180^{\circ} \mathrm{C}$; MS data were acquired in the scan mode in the $\mathrm{m} / \mathrm{z}$ range 33450 . The chemical components were identified by comparing their mass spectra with the Mass Spectral Library of NIST (Masada 1976; NIST 2002). Their retention time was compared to the retention time of authentic compounds or with literature (Adams 2007).

\section{Antibacterial activity}

Essential oils were tested against eight selected bacteria strains resistant to antibiotics, namely E-coli ATCC25922, Pseudomonas aeruginosa ATCC 27853, Staphylococcus aureus ATCC 25923, Klebsiella pneumonia ATCC 700603, Salmonella enteric spp. arizonae CIP 81-3, Listeria innocua clip 74915, Proteus mirabilis ATCC 35659, and Bacillus cereus ATCC 11778 . The in vitro antibacterial activity of the essential oil was determined by the microdilution method, according to the Clinical and Laboratory Standards Institute Recommendations (NCCLS).

Bacteria were cultured overnight in physiological saline $(0.8 \%$ of $\mathrm{NaCl})$. The optical density was observed at 625 nm. Muller-Hinton Agar (MHA) supplemented with 5\% sheep blood was poured into Petri dishes, solidified, and dried before bacterial inoculation. Six mm-sterile discs were placed on MHA growth media that had been inoculated with a suspension of test bacteria. Ten $\mu \mathrm{l}$ of essential oil and diluted essential oil (1:1, 1:2, 1:4 and 1:8 v/v of DMSO, DMSO used as a negative control) was transferred to sterile discs. Petri dishes were incubated at $37^{\circ} \mathrm{C}$ for 18 to $24 \mathrm{~h}$ aerobically, and the inhibition zones were determined and recorded after incubation complete. The diameter of the inhibition zone around the discs refers to bacterial growth inhibition. All experiments were carried out in three replicates. 


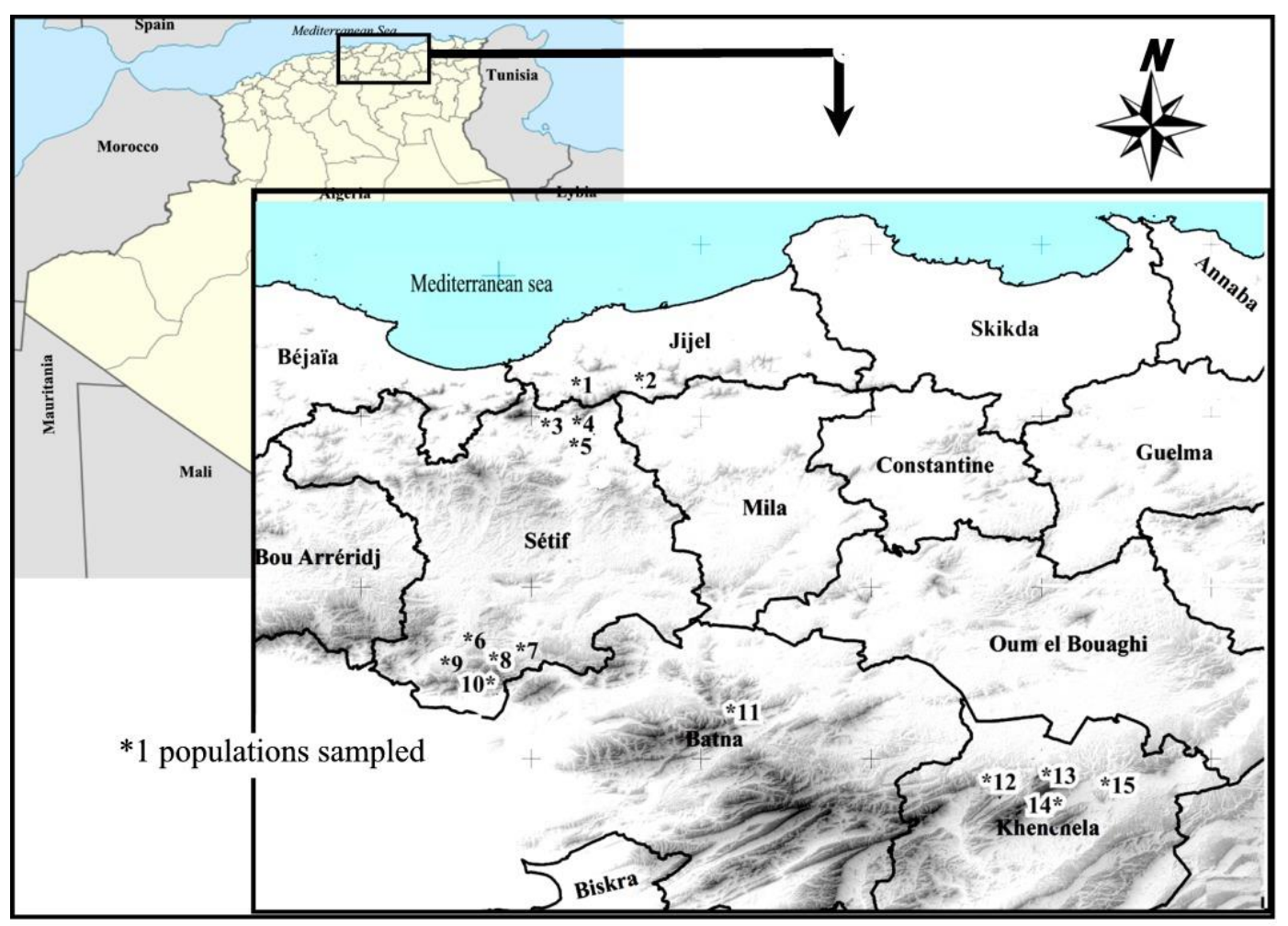

Figure 1. Sampling locations of Pinus halepensis in northern Algeria. (For the numbers (*1) see Table 1)

Table 1. Geographical coordinates of the sampling sites in northern Algeria

\begin{tabular}{|c|c|c|c|c|c|}
\hline \multirow{2}{*}{$\begin{array}{l}\text { Localities } \\
\text { Jijel }\end{array}$} & \multirow{2}{*}{\multicolumn{2}{|c|}{$\begin{array}{l}\text { Populations } \\
\text { Bir ghzala }\end{array}$}} & \multirow{2}{*}{$\begin{array}{c}\text { Altitude (m) } \\
0947\end{array}$} & \multicolumn{2}{|c|}{ Geographic coordinates } \\
\hline & 1 & & & $36^{\circ} 36^{\prime} 48.75^{\prime \prime} \mathrm{N}$ & $5^{\circ} 30^{\prime} 38.56^{\prime \prime} \mathrm{E}$ \\
\hline & 2 & Iraguene & 0767 & $36^{\circ} 35^{\prime} 10.32^{\prime \prime} \mathrm{N}$ & $5^{\circ} 34^{\prime} 51.24^{\prime \prime} \mathrm{E}$ \\
\hline \multirow[t]{3}{*}{ Setif North (Babor) } & 3 & Djouada & 1568 & $36^{\circ} 30^{\prime} 18.90^{\prime \prime} \mathrm{N}$ & $5^{\circ} 29^{\prime} 50.70^{\prime \prime} \mathrm{E}$ \\
\hline & 4 & Daassa & 0861 & $36^{\circ} 29^{\prime} 23.64 " \mathrm{~N}$ & $5^{\circ} 32^{\prime} 21.48^{\prime \prime} \mathrm{E}$ \\
\hline & 5 & Beni Bezez & 1133 & $36^{\circ} 19^{\prime} 69.03^{\prime \prime N}$ & $5^{\circ} 41^{\prime} 50.87 " \mathrm{E}$ \\
\hline \multirow[t]{5}{*}{ Setif South (Boutaleb) } & 6 & Ain laaneb & 1433 & $35^{\circ} 44^{\prime} 25.54 " \mathrm{~N}$ & $5^{\circ} 21^{\prime} 04.93 " \mathrm{E}$ \\
\hline & 7 & Bouriache & 0982 & $35^{\circ} 43^{\prime} 09.89^{\prime \prime} \mathrm{N}$ & $5^{\circ} 13^{\prime} 45.34^{\prime \prime} \mathrm{E}$ \\
\hline & 8 & Cheabet Thnia Khrouf & 1296 & $35^{\circ} 42^{\prime} 06.27^{\prime \prime} \mathrm{N}$ & $5^{\circ} 20^{\prime} 55.77 " \mathrm{E}$ \\
\hline & 9 & Chikda & 1259 & $35^{\circ} 42^{\prime} 56.19^{\prime \prime} \mathrm{N}$ & $5^{\circ} 25^{\prime} 05.09^{\prime \prime} \mathrm{E}$ \\
\hline & 10 & Sidi amor & 1054 & $35^{\circ} 42^{\prime} 16.14 " \mathrm{~N}$ & $5^{\circ} 22^{\prime} 03.088^{\prime \prime E}$ \\
\hline Batna & 11 & Seriana & 1026 & $35^{\circ} 39^{\prime} 48.90 " \mathrm{~N}$ & $6^{\circ} 11^{\prime} 53.30 " \mathrm{E}$ \\
\hline \multirow[t]{4}{*}{ Khanechela (Ouled Yakoub) } & 12 & Boussenane & 1178 & $35^{\circ} 22^{\prime} 51.60 " \mathrm{~N}$ & $6^{\circ} 54^{\prime} 05.35^{\prime \prime} \mathrm{E}$ \\
\hline & 13 & Troud & 1160 & $35^{\circ} 23^{\prime} 53.19^{\prime \prime} \mathrm{N}$ & $6^{\circ} 57^{\prime} 02.17 " \mathrm{E}$ \\
\hline & 14 & Tafrent & 1562 & $35^{\circ} 22^{\prime} 31.72 " \mathrm{~N}$ & $6^{\circ} 57^{\prime} 30.84 " \mathrm{E}$ \\
\hline & 15 & Tizi yaala & 1224 & $35^{\circ} 25^{\prime} 06.33^{\prime \prime} \mathrm{N}$ & $6^{\circ} 83^{\prime} 23.72^{\prime \prime} \mathrm{E}$ \\
\hline
\end{tabular}

The sensitivity of bacteria to the essential oils was categorized into five groups according to the diameter of the inhibition halos): Not sensitive $(-)$ (diameter $<8 \mathrm{~mm}$ ); Sensitive (+) (diameter ranges from 9 to $14 \mathrm{~mm}$ ); Very sensitive $(++)$ (diameter ranges from 15 to $19 \mathrm{~mm})$, and Extremely sensitive $(+++)$ (diameter $>20 \mathrm{~mm}$ ) (Ponce et al. 2003). Standard antibiotics were used as positive control: Gentamicin $(10 \mu \mathrm{g})$, Erythromycin $(15 \mu \mathrm{g})$, Amoxicillin $(25 \mu \mathrm{g})$, Meropenem $(10 \mu \mathrm{g})$ and oxacillin $(1 \mu \mathrm{g})$.

\section{Statistical analysis}

Principal Components Analysis (PCA) examined the relationships between terpene compounds, identified the possible population structure, and the variations in the composition of $P$. halepensis essential oil. Cluster (UPGMA) analysis applied in the original variables and the Manhattan distance analyzed the hierarchical associations between the populations. Statistical significance was determined by the three-way ANOVA and posthoc tests. Statistica (Ver. 10) carried out all statistical tests, and the antibacterial activity data are expressed as mean $\pm \mathrm{SD}$, where differences with $P$ $<0.05$ were considered significant. 


\section{RESULTS AND DISCUSSION}

The extraction of essential oils from the aerial parts of $P$. halepensis was performed by the hydro-distillation method, using a Clevenger type apparatus. The provided essential oils have different colors ranging from light yellow to transparent, with a very strong odor. The average yield of essential oil was $0.64 \pm 0.37 \%$. The highest yield $(1.34 \%)$ was from the essential oil of the Iraguene population, and the lowest yield $(0.34 \%)$ was obtained from the Tafrent population. The results indicated that altitude directly affected the yield of $P$. halepensis essential oil. The regression curve confirms yield reduction by increasing altitude (Figure 2).

The essential oils of $P$. halepensis were analyzed by Gas Chromatography and Mass Spectrometry (GC / MS). The identified components are shown in Table 2 according to retention time. Chromatographic analysis of Aleppo pine essential oils showed the presence of thirty-seven identified volatile compounds, representing of $99.40 \pm 0.5 \%$ of the total essential oil. The major compounds were caryophyllene-E $(29.06 \pm 8.5 \%)$, myrcene $(19.14 \% \pm$ $6.67 \%)$, $\alpha$-pinene $(16.86 \pm 3.35 \%)$, phenylethyl 3-methyl butanoate $(5.67 \pm 2.47 \%)$, $\alpha$-humulene $(4.81 \pm 1.43 \%)$, terpinolene $(3.94 \pm 1.60 \%)$, sabinene $(3.11 \pm 1.84 \%), \Delta 3$ carene $(2.18 \pm 1.85 \%)$ and cembrene $(2.15 \pm 1.93 \%)$, and other compounds of relatively low percentage (limonene, $\beta$-ocimene, $\beta$-pinene, germacrene-D, $\alpha$-muurolene and linalool). The essential oil of $P$. halepensis contained 14 monoterpene hydrocarbons (51.46 $\pm 9.73 \%)$, and four oxygenated monoterpenes $(1.27 \pm 1.47 \%$. The oil of Tizi yaala and Troud regions was found to be rich in myrcene (28.23-24.01\%) and $\alpha$-pinene (23.97-21.08\%). Myrcene and $\alpha$-pinene are minimal amounts in Daassa and Beni Bezez populations (Table 3).

The hydrocarbon sesquiterpenes were $37.12 \pm 9.73 \%$, which was dominated by caryophyllene-E. The high content of caryophyllene-E was found in the Beni Bezez (47\%), Daassa (40.92\%), and Iraguene (36.10\%) populations. The lowest content was found in the Tafrent population $(15.20 \%)$. The oxygenated sesquiterpenes are very low $(1.0 \pm 0.91 \%)$. Three diterpenes (cubitene, cembrene, and $\alpha$-cembrene-3Z) were also identified in $P$. halepensis essential oil. The total average of oil esters was $5.87 \pm 2.62 \%$, which were consisted of bornyl acetate

$(0.01 \%)$, geranyl acetate $(0.2 \%)$, and phenyl ethyl 3methyl butanoate $(5.67 \%)$.

The results of the chemical composition analysis of the $P$. halepensis essential oils show variability. Relationship analysis between populations was carried out by the Principal Component Analysis (PCA), and it showed that the composition of essential oil differed significantly between population, and the major compounds show a few inter-population variabilities (Figure 3).

The three-dimensional spatial projection of the populations based on the three main axes from the PCA (Figure 4) shows that the populations of Tafrent, Troud, and Beni Bezaz are distinctly separated. The rest of the populations are not separated split clearly, and their separation into homogeneous groups is less obvious.

The result of the PCA test and $P$. halepensis populations in two distinct clades are confirmed by UPGMA clusters analysis (Figure 5). This population's clustration in small groups indicates the presence of difference in the chemical composition of the essential oils.

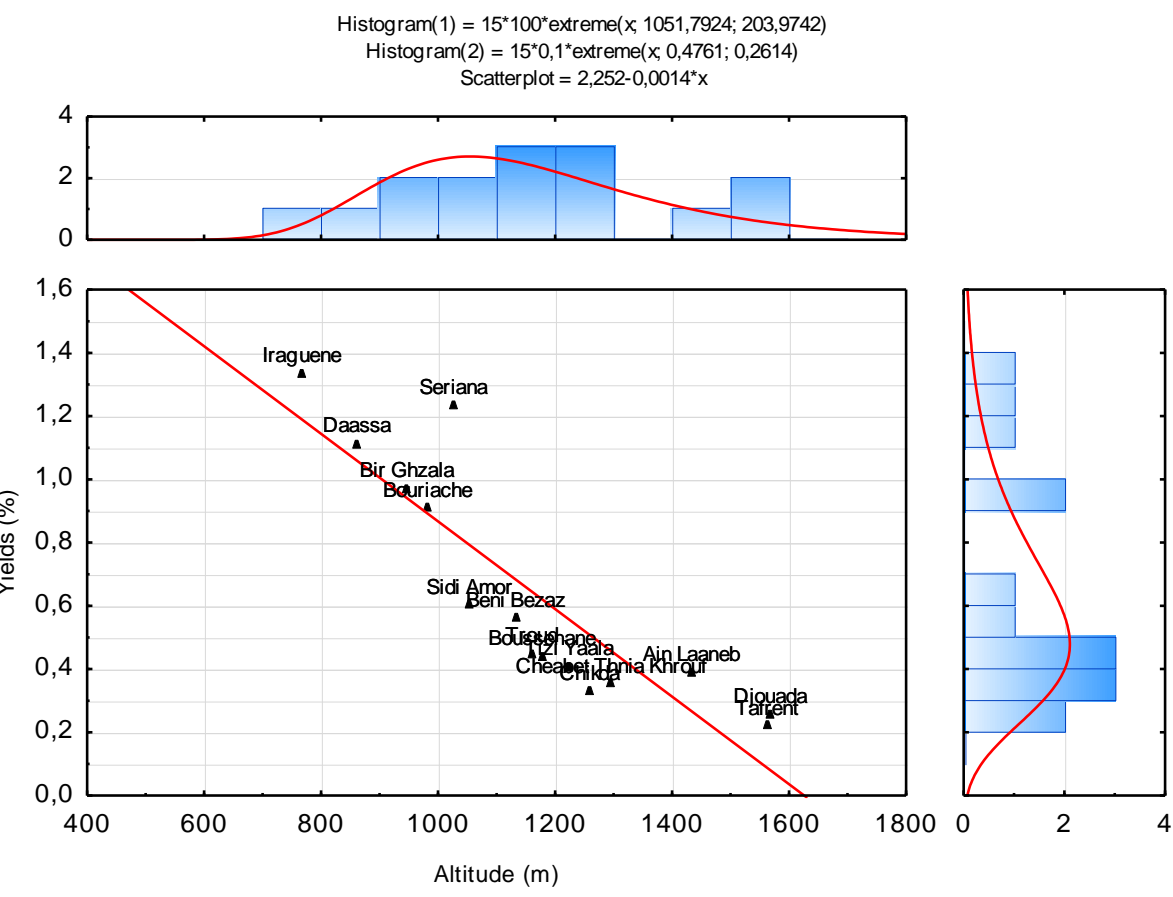

Figure 2. The yield of essential of the P. halepensis populations from Algeria 
The first clustration separated the population of Tafrent from the other populations. It is based on the presence of volatile compounds of sabinene, $\Delta 3$-carene, and terpinolene. The second clade is divided into two subbranches, i.e. the populations of Beni Bezez and Daassa, forming a subgroup characterized by a high level of caryophyllene-E and $\alpha$-humulene. The second subgroup is divided into two parts. The first part includes populations of Cheabet Thniyat Khrouf; Bouriache; Bousennene; Ain
Laanab; Djouada; Bir ghzala; Iraguene; Chikda and Seriana are characterized by the presence of caryophyllene-E, $\alpha$ pinene, and $\alpha$-humulene. The second part includes populations of Sidi Amor, Troud, and Tizi Yaala are characterized by caryophyllene-E, $\alpha$-humulene, and myrcene. Based on the UPGMA analysis, at least four chemotypes were identified in the $P$. halepensis population in the study area (Table 4).

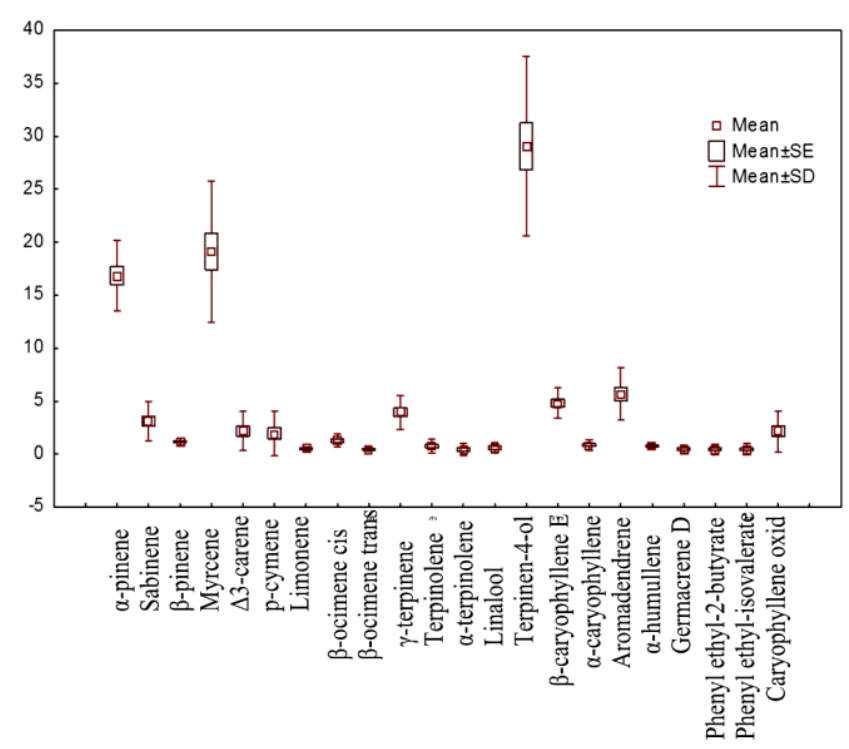

Figure 3. Variability of major components of Pinus halepensis essential oils

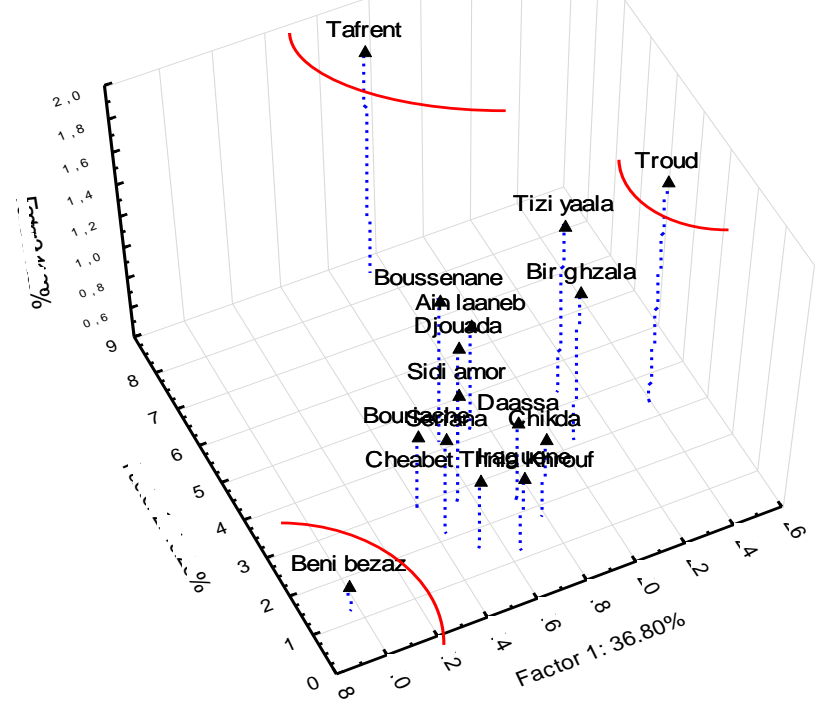

Figure 4. Three-dimensional spatial projection of Pinus halepensis populations

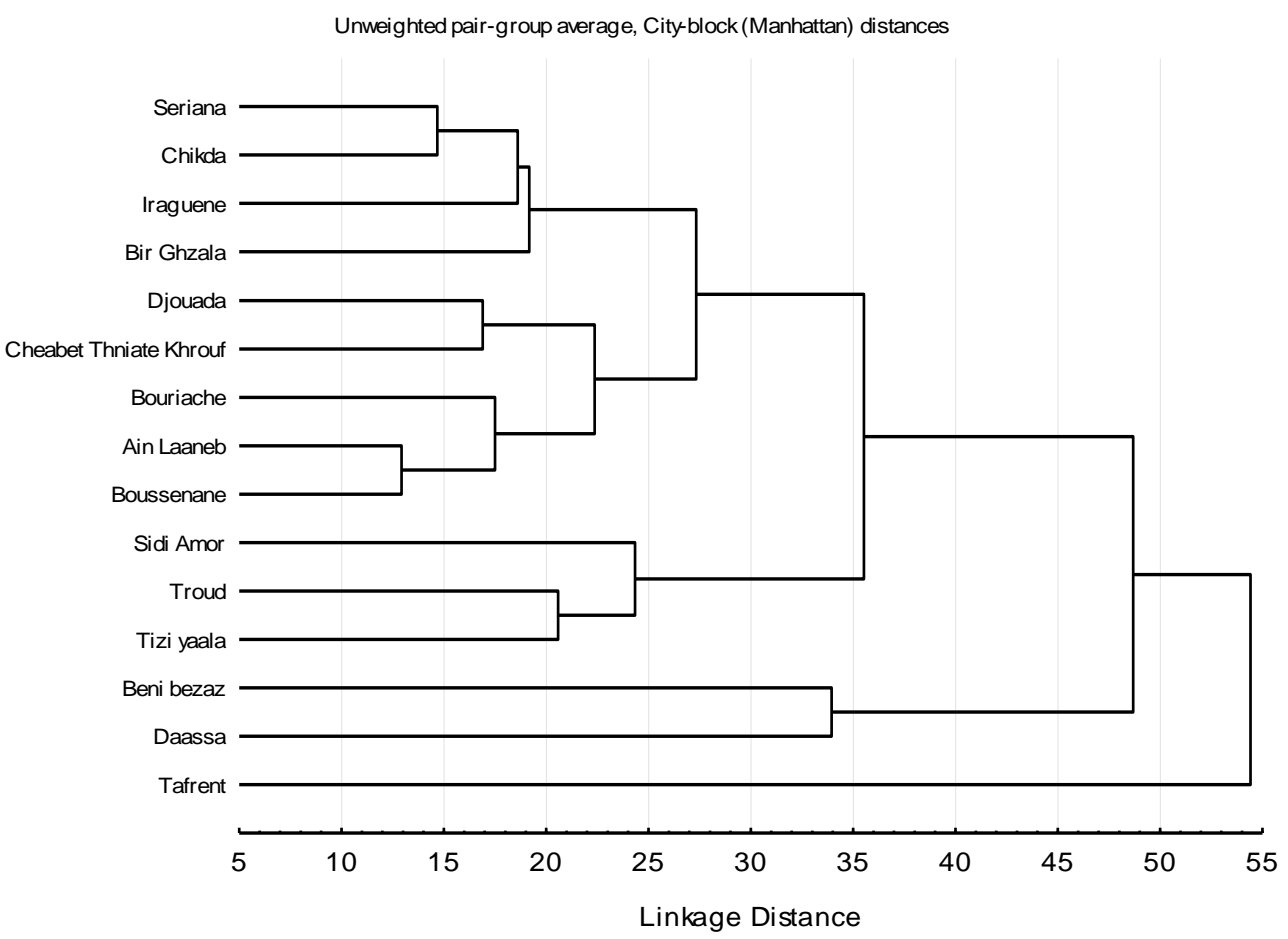

Figure 5. Dendrogram resulting from UPGMA of Pinus halepensis populations based on linkage distance 
Table 2. Chemical composition of Pinus halepensis essential oils

\begin{tabular}{|c|c|c|c|c|c|c|c|c|c|c|c|c|c|c|c|c|c|c|}
\hline Populations & & & $\begin{array}{l}\stackrel{\pi}{\mathscr{E}} \\
\stackrel{\tilde{\sigma}}{0} \\
\stackrel{0}{0}\end{array}$ & 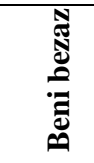 & 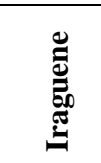 & 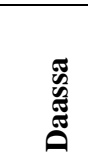 & 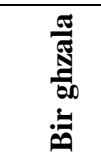 & 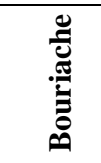 & 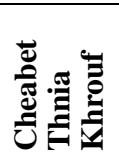 & 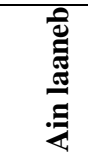 & 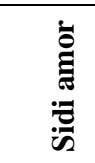 & 苞 & 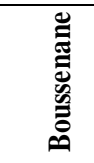 & $\underset{\mathrm{B}}{\mathrm{O}}$ & $\begin{array}{l}\frac{G}{\mathbb{T}} \\
\underset{\mathbb{F}}{\mathbb{N}} \\
: \mathbb{V}\end{array}$ & 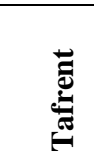 & 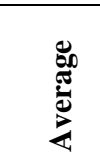 & \% \\
\hline Yields & & 1.24 & 0.26 & 0.56 & 1.34 & 1.12 & 0.98 & 0.91 & 0.36 & 0.40 & 0.61 & 0.33 & 0.44 & 0.452 & 0.41 & 0.22 & 0.64 & 0.37 \\
\hline Compounds nb & $\mathrm{KI}^{*}$ & 22 & 24 & 17 & 24 & 23 & 24 & 32 & 35 & 28 & 35 & 27 & 29 & 22 & 23 & 26 & 28 & 7 \\
\hline Total $(\%)$ & & 99.9 & 99.2 & 99.3 & 99.7 & 99.4 & 99.7 & 98.8 & 98.5 & 98.2 & 98.8 & 98.7 & 99.5 & 99.8 & 99.2 & 98.5 & 99.4 & 0.5 \\
\hline$\alpha$-thujene & 924 & 0.38 & 0.42 & 0 & 0.12 & 0.19 & 0.22 & 0.38 & 0.30 & 0.37 & 0.31 & 0.23 & 0.46 & 0.33 & 0.28 & 0.35 & 0.29 & 0.12 \\
\hline$\alpha$-pinene & 935 & 14.4 & 16.30 & 9.67 & 16.50 & 17.37 & 20.60 & 13.95 & 15.14 & 17.33 & 15.39 & 17.86 & 16.05 & 23.97 & 21.08 & 17.39 & 16.86 & 3.35 \\
\hline Camphene & 951 & 0.17 & 0.16 & 0 & 0.18 & 0.38 & 0.23 & 0.12 & 0.17 & 0.18 & 0.15 & 0.16 & 0.23 & 0.26 & 0.22 & 0.26 & 0.19 & 0.08 \\
\hline Sabinene & 974 & 2.09 & 3.61 & 1.21 & 1.14 & 2.27 & 3.10 & 2.88 & 1.52 & 4.17 & 2.70 & 1.7 & 4.15 & 3.32 & 4.30 & 8.54 & 3.11 & 1.84 \\
\hline$\beta$-pinene & 979 & 1.06 & 1.18 & 0.60 & 0.92 & 0.94 & 1.40 & 0.91 & 0.89 & 1.13 & 1.16 & 0.95 & 1.37 & 1.85 & 1.51 & 1.82 & 1.18 & 0.35 \\
\hline Myrcene & 991 & 28.1 & 20.60 & 13.40 & 21.30 & 7.74 & 20.11 & 14.58 & 16.80 & 13.9 & 29.25 & 23.69 & 14.50 & 28.23 & 24.01 & 10.90 & 19.14 & 6.67 \\
\hline$\Delta 3$-carene & 1009 & 1.00 & 1.43 & 0.60 & 2.01 & 0.57 & 2.60 & 1.23 & 0.90 & 4.28 & 1.17 & 1.14 & 4.30 & 2.66 & 1.51 & 7.33 & 2.18 & 1.85 \\
\hline$\alpha$-terpinene & 1017 & 0.17 & 0.33 & 0 & 0.09 & 0.66 & 0.45 & 0.27 & 0.19 & 0.19 & 0.25 & 0.14 & 0.23 & 0.40 & 0.43 & 0.45 & 0.28 & 0.17 \\
\hline Cymene-ortho & 1020 & 0 & 0 & 0 & 0 & 0 & 0 & 0 & 0 & 0.31 & 0 & 0.09 & 0.25 & 0 & 0 & 0.67 & 0.09 & 0.19 \\
\hline Limonene & 1030 & 0.38 & 0.54 & 0 & 0.22 & 6.61 & 0.90 & 4.28 & 1.44 & 4.78 & 0.37 & 0.84 & 3.23 & 0.55 & 4.35 & 0.71 & 1.95 & 2.11 \\
\hline$\beta$-phellandrene & 1032 & 0.45 & 0.69 & 0 & 0.34 & 0.38 & 0.68 & 0.47 & 0.35 & 0.71 & 0.46 & 0.53 & 0.65 & 0.62 & 0.65 & 0.74 & 0.51 & 0.20 \\
\hline 1,8 -cineole & 1033 & 0 & 0 & 0 & 0.22 & 0 & 0 & 0 & 0.03 & 0 & 0 & 0 & 0 & 0 & 0 & 0 & 0.02 & 0.06 \\
\hline$\beta$-Ocimene (E) & 1045 & 1.30 & 1.36 & 2.42 & 1.05 & 2.27 & 1.46 & 1.85 & 1.23 & 0.95 & 1.49 & 0.58 & 1.60 & 0.90 & 0.77 & 0 & 1.28 & 0.63 \\
\hline$\gamma$-terpinene & 1058 & 0.34 & 0.62 & 0 & 0.18 & 0.57 & 0.56 & 0.49 & 0.36 & 0.37 & 0.46 & 0.29 & 0.42 & 0.66 & 0.69 & 0.71 & 0.45 & 0.20 \\
\hline Terpinolene & 1085 & 3.30 & 5.40 & 1.51 & 1.60 & 2.64 & 4.51 & 4.59 & 2.73 & 4.18 & 3.91 & 2.32 & 4.20 & 5.16 & 5.98 & 7.03 & 3.94 & 1.60 \\
\hline Linalool & 1097 & 0 & 0 & 0 & 1.78 & 1.70 & 1.12 & 1.05 & 0.89 & 0.63 & 1.02 & 0.24 & 1.35 & 1.21 & 0 & 0 & 0.73 & 0.65 \\
\hline Terpinen-4-ol & 1185 & 0 & 0.80 & 0 & 0 & 0 & 0 & 0.71 & 0.46 & 0.43 & 0.76 & 0.2 & 0.70 & 0 & 0 & 2.16 & 0.42 & 0.58 \\
\hline$\alpha$-terpineol & 1199 & 0 & 0.40 & 0 & 0.34 & 0 & 0.01 & 0.19 & 0.36 & 0 & 0.26 & 0 & 0 & 0 & 0 & 0 & 0.10 & 0.16 \\
\hline Geranyl acetate & 1377 & 0 & 0 & 0 & 0 & 0 & 0 & 0.86 & 0.20 & 0 & 0.23 & 0 & 0.40 & 0 & 0 & 1.30 & 0.20 & 0.39 \\
\hline$\alpha$-funebrene-2-epi & 1383 & 0.72 & 0.38 & 0 & 0.68 & 0.94 & 0.45 & 0.57 & 0.48 & 0.56 & 0.52 & 0.49 & 0.70 & 0.46 & 2.13 & 0 & 0.61 & 0.49 \\
\hline$\beta$-caryophyllene (E) & 1434 & 32.1 & 27.90 & 47.00 & 36.10 & 40.92 & 31.20 & 30.47 & 27.00 & 25.64 & 21.70 & 31.19 & 31.60 & 20.32 & 17.56 & 15.20 & 29.06 & 8.50 \\
\hline$\beta$-farnesene $(\mathrm{Z})$ & 1453 & 0 & 0 & 0 & 0 & 0 & 0 & 0.24 & 0.30 & 0 & 0.22 & 0.1 & 0 & 0 & 0 & 0 & 0.06 & 0.11 \\
\hline$\alpha$-humulene & 1467 & 5.15 & 4.82 & 8.10 & 6.10 & 6.61 & 5.08 & 5.12 & 4.59 & 4 & 3.54 & 5.04 & 5.04 & 3.43 & 2.90 & 2.62 & 4.81 & 1.43 \\
\hline Germacrene D & 1490 & 1.10 & 1.40 & 1.21 & 0.00 & 1.32 & 0 & 1.38 & 0 & 0.81 & 1.21 & 0.95 & 0.90 & 0.66 & 0.92 & 1.17 & 0.87 & 0.50 \\
\hline Phenylethyl 3-M.butanoate & 1496 & 4.50 & 4.53 & 7.85 & 6.46 & 4.10 & 4.00 & 4.58 & 10.03 & 8.74 & 4.47 & 7.24 & 2.65 & 2.97 & 3.20 & 9.71 & 5.67 & 2.47 \\
\hline$\alpha$-muurolene & 1506 & 0.79 & 0.49 & 0.60 & 0.60 & 0.94 & 0.30 & 1.04 & 0.87 & 0.84 & 1.05 & 0.88 & 1.32 & 0.77 & 0.60 & 0.56 & 0.78 & 0.26 \\
\hline$\Delta$-amorphene & 1525 & 0.58 & 0 & 0.60 & 0.50 & 0 & 0.07 & 0.48 & 0.66 & 0.66 & 0.59 & 0.45 & 0.11 & 0.44 & 0.50 & 1.49 & 0.48 & 0.37 \\
\hline Cadina1,4-diene trans & 1543 & 0.48 & 0 & 0.91 & 0 & 0 & 0 & 0.52 & 0.29 & 0.38 & 0.15 & 0.22 & 0.40 & 0 & 0 & 0 & 0.22 & 0.27 \\
\hline $\begin{array}{l}\text { Elemol } \\
\text { Elem }\end{array}$ & 1555 & 1.30 & 0 & 0 & 0 & 0 & 0.02 & 0.17 & 0.08 & 0 & 0.08 & 0 & 0 & 0 & 0 & 0 & 0.11 & 0.33 \\
\hline Caryophyllene oxide & 1595 & 0 & 0.63 & 1.81 & 0 & 0 & 0 & 0.54 & 0.72 & 0.73 & 0.49 & 0.39 & 0.93 & 0 & 0 & 0.63 & 0.46 & 0.50 \\
\hline Guaiol & 1605 & 0 & 0 & 0 & 0 & 0.02 & 0.01 & 0.22 & 0.50 & 0 & 0.37 & 0 & 0 & 0 & 0.37 & 0 & 0.10 & 0.17 \\
\hline Humulene epoxide II & 1622 & 0 & 0 & 0 & 0 & 0 & 0 & 0 & 0.29 & 0 & 0.34 & 0 & 0 & 0 & 0 & 1.10 & 0.12 & 0.29 \\
\hline$\alpha$-muurolol & 1665 & 0 & 0 & 0 & 0.3 & 0 & 0 & 0 & 0.34 & 0 & 0.11 & 0 & 0 & 0 & 0 & 0 & 0.05 & 0.11 \\
\hline$\alpha$-eudesmol & 1667 & 0 & 0 & 0 & 0 & 0.04 & 0 & 0.16 & 1.25 & 0 & 0.14 & 0 & 0.63 & 0 & 0 & 0 & 0.15 & 0.35 \\
\hline Cubitene & 1937 & 0 & 1.29 & 0.60 & 0 & 0.20 & 0 & 0.68 & 0.71 & 0.14 & 0.45 & 0 & 0.35 & 0 & 1.92 & 0.54 & 0.46 & 0.55 \\
\hline$\alpha$-cembrene (3Z) & 1967 & 0 & 0 & 0 & 0 & 0 & 0 & 0 & 0.52 & 0.13 & 0.30 & 0 & 0 & 0 & 0 & 0.06 & 0.06 & 0.15 \\
\hline Cembrene & 2059 & 0 & 3.90 & 1.21 & 1 & 0 & 0.60 & 3.84 & 5.88 & 1.61 & 3.74 & 0.81 & 0.73 & 0.62 & 3.30 & 5.02 & 2.15 & 1.93 \\
\hline
\end{tabular}

Note: * KI = Kovats index on a HP-5ms (apolar capillary column) 
Table 3. Chemical classes of Pinus halepensis essential oils

\begin{tabular}{|c|c|c|c|c|c|c|c|c|c|c|c|c|c|c|c|c|c|}
\hline Populations & 莺 & $\begin{array}{l}\frac{\pi}{\tilde{J}} \\
\stackrel{\tilde{J}}{0} \\
\stackrel{0}{0}\end{array}$ & 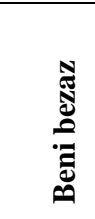 & 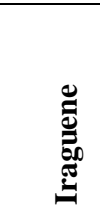 & 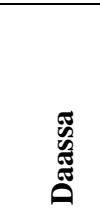 & 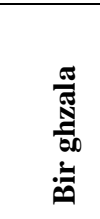 & 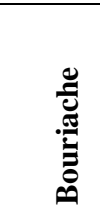 & 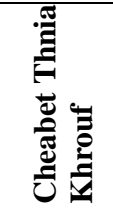 & 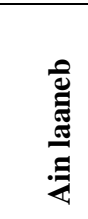 & 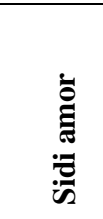 & 宽 & 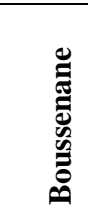 & 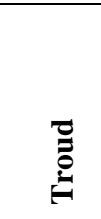 & 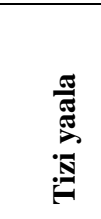 & $\underset{\frac{\vec{J}}{\tilde{J}}}{\vec{E}}$ & 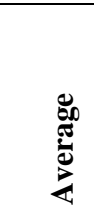 & के \\
\hline Monoterpene hydrocarbons & 53.12 & 52.64 & 29.41 & 45.65 & 42.59 & 56.82 & 46 & 42.02 & 52.85 & 57.07 & 50.52 & 51.64 & 68.91 & 65.78 & 56.9 & 51.46 & 9.73 \\
\hline Oxygenated monoterpenes & 0 & 1.2 & 0 & 2.34 & 1.7 & 1.13 & 1.95 & 1.74 & 1.06 & 2.04 & 0.44 & 2.05 & 1.21 & 0 & 2.16 & 1.27 & 0.83 \\
\hline Sesquiterpene hydrocarbons & 40.92 & 35.66 & 58.42 & 44.2 & 50.73 & 37.1 & 40.56 & 34.94 & 32.89 & 29.54 & 39.32 & 40.07 & 26.08 & 24.76 & 21.65 & 37.12 & 9.73 \\
\hline Oxygenated sesquiterpenes & 1.3 & 0.63 & 1.81 & 0.3 & 0.09 & 0.03 & 1.09 & 3.31 & 0.73 & 1.63 & 0.39 & 1.56 & 0 & 0.37 & 1.73 & 1 & 0.91 \\
\hline Diterpenes & 0 & 5.19 & 1.81 & 1 & 0.2 & 0.6 & 4.52 & 7.11 & 1.88 & 4.49 & 0.81 & 1.08 & 0.62 & 5.22 & 5.62 & 2.68 & 2.39 \\
\hline Ester & 4.5 & 4.53 & 7.85 & 6.46 & 4.1 & 4 & 5.44 & 10.32 & 8.74 & 4.7 & 7.24 & 3.05 & 2.97 & 3.2 & 11.01 & 5.87 & 2.62 \\
\hline
\end{tabular}

Table 4. Chemotypes identified in Pinus halepensis oils

\begin{tabular}{|c|c|}
\hline Chemotypes & Populations \\
\hline Sabinene - $\Delta 3$-carene - terpinolene & Tafrent \\
\hline$\beta$-caryophyllene-E - $\alpha$-pinene - $\alpha$-humulene & Cheabet Thniyat khrouf; Bouriache; Bousennene; Ain Laanab; Djouada; Bir ghzala; Iraguene; Chikda and Seriana \\
\hline$\beta$-caryophyllene-E - $\alpha$-pinene - myrcene & Sidi Amor; Troud and Tizi Yaala \\
\hline$\beta$-caryophyllene-E - $\alpha$-humulene & Beni Bezez and Daassa \\
\hline
\end{tabular}


The antibacterial activity of $P$. halepensis essential oils was evaluated by the disk diffusion method against eight bacterial species. The tested bacteria showed high sensitivity to the essential oil of $P$. halepensis, except $E$. coli and $P$. aeruginosa (Table 5). Almost all the essential oils can inhibit the growth of $S$. aureus, K. pneumonia, $S$. enteric, L. innocua, B. cereus, and $P$. mirabilis.

The results showed that $E$. coli and $P$. aeruginosa were resistant to all undiluted $P$. halepensis essential oils. $S$. aureus and $K$. pneumonia were the most sensitive bacteria to $P$. halepensis essential oils with a diameter of zone inhibition ranging from 10 to $32 \mathrm{~mm}$. However, bacterial sensitivity was decreased in the essential oil diluted of $1 / 8$ Undiluted essential oils from Tafrent, and Cheabet Thniat Khrouf populations were effective against $S$. aureus.

The results in Table 6 showed that sampling locations, doses, and bacterial species, and their interactions are very highly significant $(\mathrm{P}<0.001)$.

The undiluted essential oil showed the most potent effect compared to the diluted oils. The most effective oils against the tested bacteria were those of $P$. halepensis collected from Boussenen and Ain Laaneb (group a). The oil of P. halepensis collected from Daassa, and Beni Bezaz showed the weakest antibacterial activity (group i) (Table 7).

The antibiotic susceptibility test showed that the antibacterial activity of standard antibiotics varied according to the bacterial species. The tested antibiotic (meropenem) showed a higher growth inhibition than the oils against the tested bacteria (group a) (Table 8).

Zone inhibition of $P$. halepensis oils ranges from 5.86 to $3.60 \mathrm{~mm}$ at oil concentrations of $100 \%$ (undiluted) $12.5 \%$ (diluted $1 / 8$ ) so that its activity was grouped in the last groups ( $\mathrm{f}, \mathrm{g}, \mathrm{h}$ and $\mathrm{i}$ ). The most sensitive isolate is $\mathrm{L}$. innocua, with an inhibition zone average equals of 17.26 mm. The most resistant to $P$. halepensis essential oil was $P$. aeruginosa and $S$. enterica with inhibition zones average of 8.19 and $5.06 \mathrm{~mm}$, respectively (Table 9 ).

The desirability profile of $P$. halepensis essential oils against the tested bacteria had a prediction value of 0.38287 (Figure 6). The predictive value of essential oils was low for all populations. The oil concentrations used in this study results in low activity against the bacteria tested with a predictive value of 0.3984 . The antibiotic oxacillin has a lower activity than that of the prediction. The desirability test has shown that the tested bacterial species have lower values than that of prediction.

\section{Discussion}

The yield of $P$. halepensis essential oil varied widely, with an average of $0.64 \pm 0.37 \%$. These results are consistent with the results of previous studies conducted in Algeria (Dob et al. 2005, 2007; Fekih et al. 2015; AbiAyad et al. 2011; Djerrad et al. 2015); in Marocco (Hmamouchi et al. 2001); in Italy (Macchioni et al. 2003); in Greece (Roussis et al. 1995), in Turkey (Ustun et al. 2012; Tumen et al. 2010), in Portugal (Rodigues et al. 2017) and in Albania (Kreainda et al. 2018). Generally, the yields of $P$. halepensis essential oil varies according to origin (Nam et al. 2014; Mohareb et al. 2016; Djerrad et al.
2015; Fekih et al. 2014). This variability is attributed to ecological factors, geographic origin, climate, altitude, growth stage, picking period, conservation of plant material, and extraction methods (Regnault-Roger 1997; Vekiari et al. 2002). The chemical composition of $P$. halepensis essential oils is complex, and their components are varied. The results of this study are consistent with those obtained in other North African populations and in the Mediterranean basin. The main compounds of essential oil in this study are similar to the oil of the same species collected in Morocco, Italy, Greece, and Corce, with the main compounds, are $\beta$-caryophyllene, $\alpha$-pinene and myrcene (Russis et al. 1995; Lahlou et al. 2003; Macchioni et al. 2003; Efestathia et al. 2014; Nam et al. 2014; Bouyahya et al. 2019.

The results of this study indicated that the concentration of the $\Delta 3$-carene was low $(2.18 \pm 1.85 \%)$; however, this compound is the main compound of the Portugal population beside $\alpha$-pinene and myrcene (Rodrigues et al. 2017). Essential oil from the population of Turkey and Libya showed high content of $\beta$-pinene and $\alpha$ - (Ustun et al. 2012; Ahmed et al. 2016). The essential oil of this study showed low content of $\beta$-pinene $(0.2-2.2 \%)$. The essential oil of $P$. halepensis population in Greece show the dominance of caryophyllene-E and thunbergol (32.2\% and $29.2 \%$, resp.) (Mirtic et al. 2019). Thunbergol was present in the essential oils from Ghazaouet (Abi-ayed et al. 2011) and Egypt (El-Baha et al. 2016), but it was absent in this study.

The results of this study also showed that chemical compounds are different from those obtained from different areas in North Algeria. The main compounds of essential oil from Sidi Ferradj, Djelfa, and Saida were dominated by $\beta$-caryophyllène-Z, and humulene (Dob et al. 2005, 2007). The main compounds of essential oil from Djelfa and Batna was y $\beta$-caryophyllène- $Z$ and myrcene (Djerrad et al. 2015). The essential oils from Tebessa and Batna were dominated by $\beta$-caryophyllène- $Z$ - $\alpha$-pinene (Djerrad et al. 2015). Besides, the essential oil from the Telemen was dominated by myrcene - $\alpha$-pinene (Fekih et al. 2015), and the essential oil from the Ghazaouet was dominated by caryophyllene oxide (48\%) (Abi Ayed et al. 2016).

The essential oils in this study contain very low of caryophyllene oxide $(0.39-1.81 \%)$. Determination of essential oil compounds from several populations could be used for determining their chemotypes. Several studies have investigated the antibacterial activity of essential oils obtained from different plant parts of P.halepensis (needles, roots, buds or cones) (Hmamouchi et al. 2001; Abi Ayed et al. 2011; Ghanemi et al. 2013; Ghalem 2014; Mohareb et al. 2016; Ashmawy et al. 2018; Bouyahya et al. 2019, Mirtic et al.2019). The antibacterial effect of $P$. halepensis essential oil is by the irreversible damage of bacterial cell wall and membrane, and resulting in leakages of proteins and nucleic acids (DNA \& RNA) out of the cell (Montironi et al. 2016). A study by Fekih et al. (2014) showed that the essential oils of $P$. halepensis from Tlemcen are ineffective against $S$. aurens, $B$. cerus, $L$. monocytagenes, $K$. pneumoneae, $P$. aeruginosa, E. coli, $P$. mirabilis and $S$. typhimurium strains. 
Table 5. Antibacterial activity of the essential oils of Pinus halepensis

\begin{tabular}{|c|c|c|c|c|c|c|c|c|c|}
\hline Populations & 奇 & $\begin{array}{l}\tilde{8} \\
\dot{8} \\
1\end{array}$ & 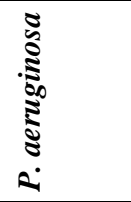 & 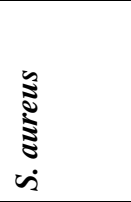 & 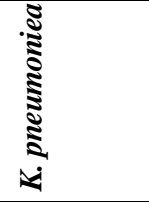 & 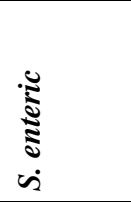 & 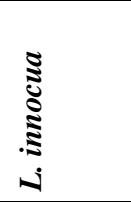 & 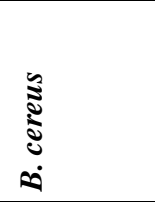 & 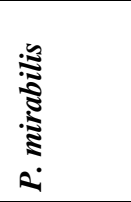 \\
\hline \multirow[t]{4}{*}{ Daassa } & 1 & 0 & 0 & 0 & 0 & 0 & $7 \pm 0$ & 0 & 0 \\
\hline & $1 / 2$ & 0 & 0 & 0 & 0 & 0 & $9.7 \pm 0.6$ & 0 & 0 \\
\hline & $1 / 4$ & 0 & 0 & 0 & 0 & 0 & $8 \pm 0$ & $8 \pm 0$ & 0 \\
\hline & $1 / 8$ & 0 & 0 & 0 & 0 & 0 & $7 \pm 0$ & $8 \pm 0$ & 0 \\
\hline \multirow[t]{4}{*}{ Beni bezaz } & 1 & 0 & 0 & 0 & 0 & 0 & $8 \pm 0$ & $6.8 \pm 0.8$ & 0 \\
\hline & $1 / 2$ & 0 & 0 & 0 & 0 & 0 & $8 \pm 0$ & $7.5 \pm 0.5$ & 0 \\
\hline & $1 / 4$ & 0 & 0 & 0 & 0 & 0 & 0 & $8.3 \pm 0.6$ & 0 \\
\hline & $1 / 8$ & 0 & 0 & 0 & 0 & 0 & 0 & $9 \pm 0$ & 0 \\
\hline \multirow[t]{4}{*}{ Tafrent } & 1 & 0 & 0 & 0 & $31.7 \pm 2$ & $13.7 \pm 1.2$ & 0 & 0 & $19.3 \pm 6.1$ \\
\hline & $1 / 2$ & 0 & 0 & $15 \pm 2$ & $17.33 \pm 0.6$ & $14 \pm 0$ & 0 & 0 & $20 \pm 0$ \\
\hline & $1 / 4$ & 0 & 0 & $12.3 \pm 0.6$ & $14 \pm 1$ & 0 & 0 & 0 & $18 \pm 1$ \\
\hline & $1 / 8$ & 0 & 0 & $13.3 \pm 2.9$ & $10 \pm 0$ & 0 & 0 & 0 & $9.7 \pm 0.6$ \\
\hline \multirow[t]{4}{*}{ Tizi yaala } & 1 & 0 & 0 & $25 \pm 1$ & $30.3 \pm 0.6$ & 0 & $8.5 \pm 0.5$ & 0 & $10.2 \pm 0.3$ \\
\hline & $1 / 2$ & 0 & 0 & $20.2 \pm 1.3$ & $17.8 \pm 0.8$ & 0 & $10.5 \pm 0.5$ & 0 & $7.7 \pm 0.5$ \\
\hline & $1 / 4$ & 0 & 0 & $12.8 \pm 0.8$ & $7 \pm 0$ & 0 & $7.7 \pm 1.2$ & $8.3 \pm 0.6$ & 0 \\
\hline & $1 / 8$ & 0 & 0 & $10.3 \pm 1.5$ & 0 & 0 & 0 & $8 \pm 0$ & 0 \\
\hline \multirow[t]{4}{*}{ Troud } & 1 & 0 & 0 & $25.3 \pm 4.2$ & $28.7 \pm 0.6$ & 0 & $8.7 \pm 0.6$ & $10 \pm 0$ & 0 \\
\hline & $1 / 2$ & 0 & 0 & $12 \pm 1$ & $14.3 \pm 1.2$ & 0 & $7 \pm 1$ & $9 \pm 0$ & $9.7 \pm 0.6$ \\
\hline & $1 / 4$ & 0 & 0 & $11.3 \pm 1.5$ & $9.3 \pm 0.6$ & 0 & $7.3 \pm 1.2$ & 0 & 0 \\
\hline & $1 / 8$ & 0 & 0 & $10.3 \pm 0.6$ & $6.3 \pm 0.6$ & 0 & 0 & 0 & 0 \\
\hline \multirow{4}{*}{ Sidi amor } & 1 & 0 & 0 & $30 \pm 0$ & $30.7 \pm 1.2$ & 0 & $7.3 \pm 0.6$ & $10.3 \pm 0.6$ & $8 \pm 0$ \\
\hline & $1 / 2$ & 0 & 0 & $20.3 \pm 2.5$ & $14 \pm 0$ & 0 & $9.7 \pm 0.6$ & $7.8 \pm 0.8$ & $7.2 \pm 1$ \\
\hline & $1 / 4$ & 0 & 0 & $13 \pm 1.73$ & $8.3 \pm 0.6$ & 0 & $8 \pm 0$ & 0 & 0 \\
\hline & $1 / 8$ & 0 & 0 & $11 \pm 1.73$ & $7.3 \pm 0.6$ & 0 & $7 \pm 0$ & 0 & 0 \\
\hline \multirow[t]{4}{*}{ Seriana } & 1 & 0 & 0 & $20.0 \pm 0.5$ & 0 & 0 & 0 & $8 \pm 0$ & 0 \\
\hline & $1 / 2$ & 0 & 0 & $10.3 \pm 0.6$ & 0 & 0 & 0 & $8 \pm 0$ & 0 \\
\hline & $1 / 4$ & 0 & 0 & $8.3 \pm 0.6$ & 0 & 0 & 0 & $8 \pm 0$ & 0 \\
\hline & $1 / 8$ & 0 & 0 & 0 & 0 & 0 & 0 & $8 \pm 0$ & 0 \\
\hline \multirow{4}{*}{ Ain laaneb } & 1 & 0 & 0 & $18 \pm 2$ & 0 & $7 \pm 0$ & $9 \pm 0$ & $11.3 \pm 0.6$ & $8.3 \pm 0.6$ \\
\hline & $1 / 2$ & 0 & 0 & $13 \pm 1.7$ & $13.3 \pm 1.5$ & $7.3 \pm 0.6$ & $9.7 \pm 0.6$ & $10.5 \pm 0.5$ & $8 \pm 0$ \\
\hline & $1 / 4$ & 0 & 0 & $10.3 \pm 0.6$ & $9 \pm 1$ & $7.3 \pm 1.2$ & $9.7 \pm 0.6$ & $12.8 \pm 0.3$ & 0 \\
\hline & $1 / 8$ & 0 & 0 & $8 \pm 0$ & $9.7 \pm 0.6$ & $7.7 \pm 0.6$ & $10 \pm 0$ & $11.7 \pm 1.2$ & 0 \\
\hline \multirow[t]{4}{*}{ Boussenane } & 1 & 0 & 0 & $20.7 \pm 1.2$ & $9.7 \pm 0.6$ & $7.6 \pm 0.6$ & $11 \pm 1.7$ & $12.3 \pm 1.5$ & $8 \pm 1$ \\
\hline & $1 / 2$ & 0 & 0 & $16 \pm 2$ & $8.3 \pm 0.6$ & $8 \pm 0$ & $10.7 \pm 0.6$ & $12.3 \pm 0.6$ & $7.3 \pm 0.6$ \\
\hline & $1 / 4$ & 0 & 0 & $12.7 \pm 2.5$ & $7.7 \pm 0.6$ & $7.6 \pm 0.6$ & $9 \pm 1$ & $15.7 \pm 1.2$ & 0 \\
\hline & $1 / 8$ & 0 & 0 & $11.7 \pm 0.6$ & $7 \pm 0$ & $7 \pm 0$ & $9.3 \pm 1.2$ & $12.3 \pm 2.3$ & 0 \\
\hline \multirow[t]{4}{*}{ Bouriache } & 1 & 0 & 0 & $17 \pm 3.6$ & $11.8 \pm 0.3$ & $6.6 \pm 1.2$ & $10 \pm 1.7$ & $13.3 \pm 1.3$ & $7.7 \pm 0.6$ \\
\hline & $1 / 2$ & 0 & 0 & $10 \pm 1$ & $10.3 \pm 0.6$ & $8 \pm 0$ & $8 \pm 0$ & $8 \pm 0$ & $8.3 \pm 0.6$ \\
\hline & $1 / 4$ & 0 & 0 & $9.7 \pm 0.6$ & $8.2 \pm 0.3$ & $8 \pm 0$ & $8.7 \pm 2.1$ & $12.3 \pm 1$ & 0 \\
\hline & $1 / 8$ & 0 & 0 & $7.7 \pm 0.6$ & 0 & 0 & $8.7 \pm 0.6$ & $13 \pm 0.8$ & 0 \\
\hline \multirow[t]{4}{*}{ Cheabet Thnia Khrouf } & 1 & 0 & 0 & $8.7 \pm 0.6$ & 0 & 0 & $8 \pm 0$ & 0 & $8.3 \pm 0.6$ \\
\hline & $1 / 2$ & 0 & 0 & $15 \pm 0$ & $13 \pm 1.7$ & 0 & $8 \pm 0$ & 0 & $8 \pm 0$ \\
\hline & $1 / 4$ & 0 & 0 & 0 & $12.7 \pm 2.1$ & 0 & 0 & 0 & 0 \\
\hline & $1 / 8$ & 0 & 0 & $8 \pm 0$ & $11.7 \pm 2.3$ & 0 & 0 & 0 & 0 \\
\hline Bir ghzala & 1 & 0 & 0 & $14.3 \pm 1.2$ & 0 & 0 & $12 \pm 1$ & $9.5 \pm 0.5$ & 0 \\
\hline & $1 / 2$ & 0 & 0 & $12 \pm 1.7$ & 0 & 0 & $12 \pm 1.7$ & $8.17 \pm 0.3$ & 0 \\
\hline & $1 / 4$ & 0 & 0 & $14.7 \pm 2.5$ & 0 & 0 & 0 & $7.33 \pm 0.6$ & 0 \\
\hline & $1 / 8$ & 0 & 0 & $10.3 \pm 2.3$ & 0 & 0 & 0 & $7 \pm 0$ & $7.7 \pm 0.6$ \\
\hline Djouada & 1 & 0 & 0 & $11.7 \pm 0.6$ & 0 & 0 & $10.3 \pm 1.5$ & $10.3 \pm 0.6$ & 0 \\
\hline & $1 / 2$ & 0 & 0 & $10.3 \pm 0.6$ & $7.67 \pm 1.2$ & 0 & $8 \pm 0$ & $9.3 \pm 0.6$ & 0 \\
\hline & $1 / 4$ & 0 & 0 & $8.8 \pm 0.3$ & $7 \pm 0$ & 0 & $8.7 \pm 2.1$ & $8 \pm 0$ & 0 \\
\hline & $1 / 8$ & 0 & 0 & 0 & $7 \pm 0$ & 0 & $8.3 \pm 1.5$ & $8 \pm 0$ & $8 \pm 0$ \\
\hline Iraguene & 1 & 0 & 0 & 0 & 0 & 0 & $9 \pm 0$ & $14.33 \pm 0.6$ & 0 \\
\hline & $1 / 2$ & 0 & 0 & 0 & 0 & 0 & $8.7 \pm 0.6$ & $10 \pm 0$ & 0 \\
\hline & $1 / 4$ & 0 & 0 & 0 & 0 & 0 & $8.7 \pm 0.6$ & $8.17 \pm 0.3$ & 0 \\
\hline & $1 / 8$ & 0 & 0 & 0 & 0 & 0 & $10 \pm 0$ & $8.67 \pm 0.6$ & 0 \\
\hline Chikda & 1 & 0 & 0 & $20 \pm 0$ & 0 & 0 & $12 \pm 1$ & $17.67 \pm 1.7$ & 0 \\
\hline & $1 / 2$ & 0 & 0 & $8.7 \pm 1.2$ & $7 \pm 0$ & 0 & $12 \pm 1.7$ & 0 & 0 \\
\hline & $1 / 4$ & 0 & 0 & $11.3 \pm 1.5$ & $8 \pm 1$ & 0 & 0 & $11.67 \pm 0.9$ & 0 \\
\hline & $1 / 8$ & 0 & 0 & $8 \pm 0$ & $8 \pm 0$ & 0 & 0 & $9 \pm 1.4$ & 0 \\
\hline Antibiotics & Gentamicin & $23 \pm 0$ & $19.3 \pm 0.6$ & $25.7 \pm 0.6$ & $20.3 \pm 0.6$ & $7.3 \pm 0.6$ & $18.3 \pm 0.6$ & 0 & $18.3 \pm 0.6$ \\
\hline & Eurythmy & $10.7 \pm 0.6$ & $14.7 \pm 0.6$ & $35 \pm 1$ & $21.7 \pm 0.6$ & $11.3 \pm 0.6$ & $30.7 \pm 0.6$ & $19.7 \pm 0.6$ & $27.3 \pm 0.6$ \\
\hline & Amoxicillin & $22 \pm 1$ & $12 \pm 1$ & 0 & $14.3 \pm 0.6$ & 0 & $29.7 \pm 0.6$ & $22.7 \pm 0.6$ & $30.3 \pm 0.6$ \\
\hline & Meropenem & $35 \pm 1$ & $27.7 \pm 0.6$ & $30.3 \pm 0.6$ & $29.7 \pm 0.6$ & $26 \pm 0$ & $32.3 \pm 0.6$ & $14.3 \pm 0.6$ & $32.7 \pm 0.6$ \\
\hline & Oxacillin & 0 & 0 & 0 & $17.7 \pm 0.6$ & 0 & $19.3 \pm 0.6$ & 0 & $10.3 \pm 0.6$ \\
\hline
\end{tabular}


Table 6. Main and interactions effects of essential oils of Pinus halepensis

\begin{tabular}{llll}
\hline Source & df & F & P \\
\hline Main Effects & 14 & 143.70 & $.0000 * * *$ \\
$\quad$ Sampling locations & 8 & 47297.68 & $.0000 * * *$ \\
Doses & 7 & 12069.2 & $.0000 * * *$ \\
$\quad$ Species of bacteria & & & $.0000 * * *$ \\
Interaction & 112 & 43.37 & $.0000 * * *$ \\
Sampling locations * Doses & 98 & 67.57 & $.0000 * * *$ \\
Sampling locations * Species of bacteria & 56 & 3372.36 & $.0000 * * *$ \\
Doses * Species of bacteria & 784 & 25.83 & \\
Sampling locations * Doses * Species of bacteria & & & \\
\hline
\end{tabular}

Note: Very highly significant $(\mathrm{P}<0.001)$

Table 7. The effectiveness of $P$. halepensis essential oils from several sampling sites against eight bacteria species $($ LSD $0.05=0.175)$

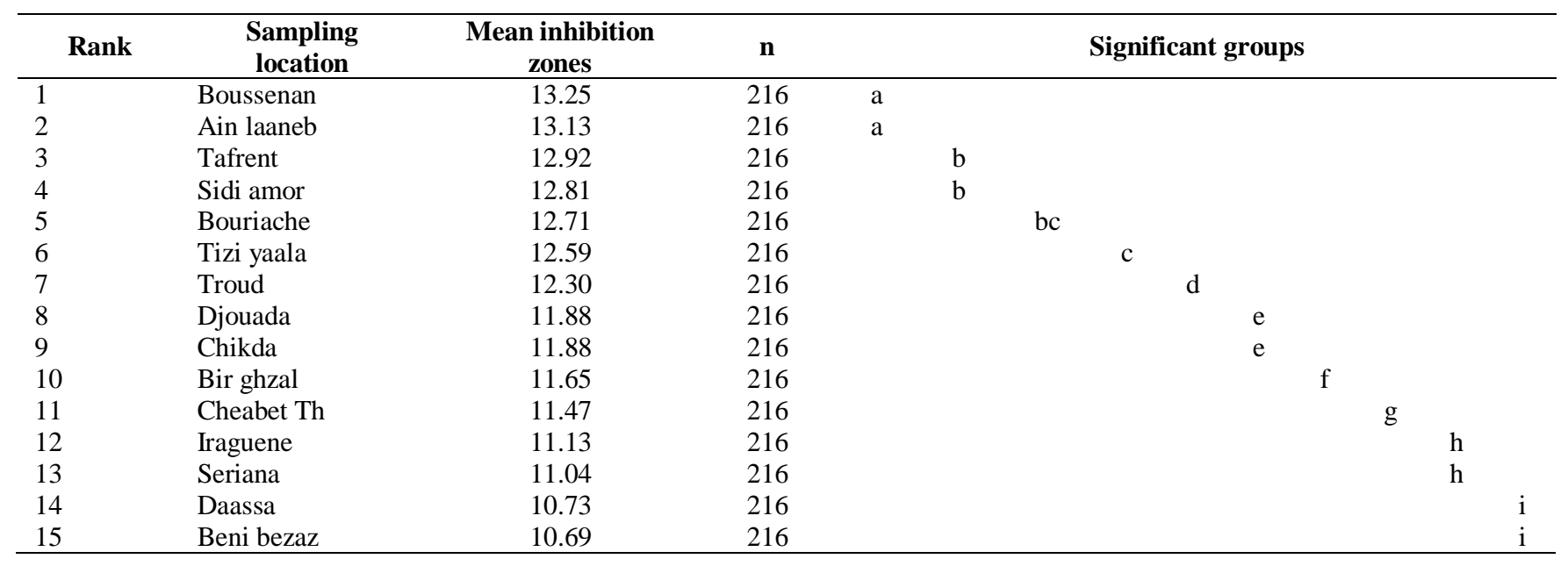

Table 8. The effect of oil dilutions on the inhibitory zone of tested bacteria (LSD $0.05=0.135$ )

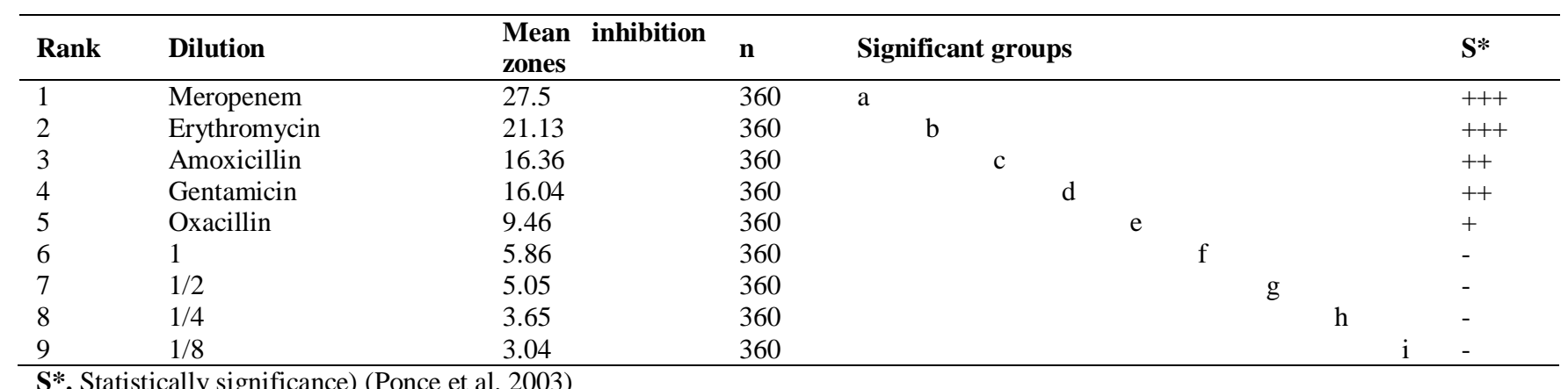

Table 9. Sensitivity groups of tested bacteria to Pinus halepensis essential oils

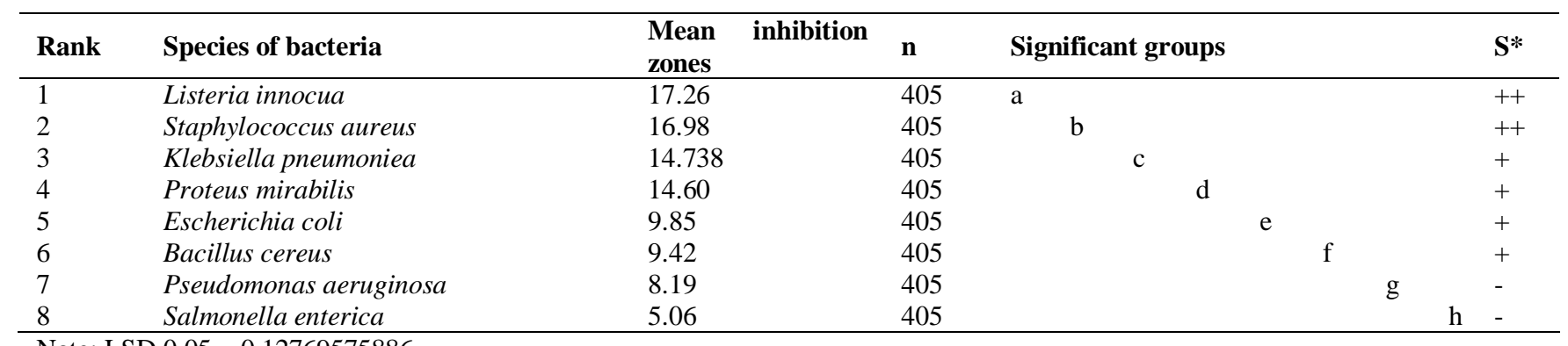




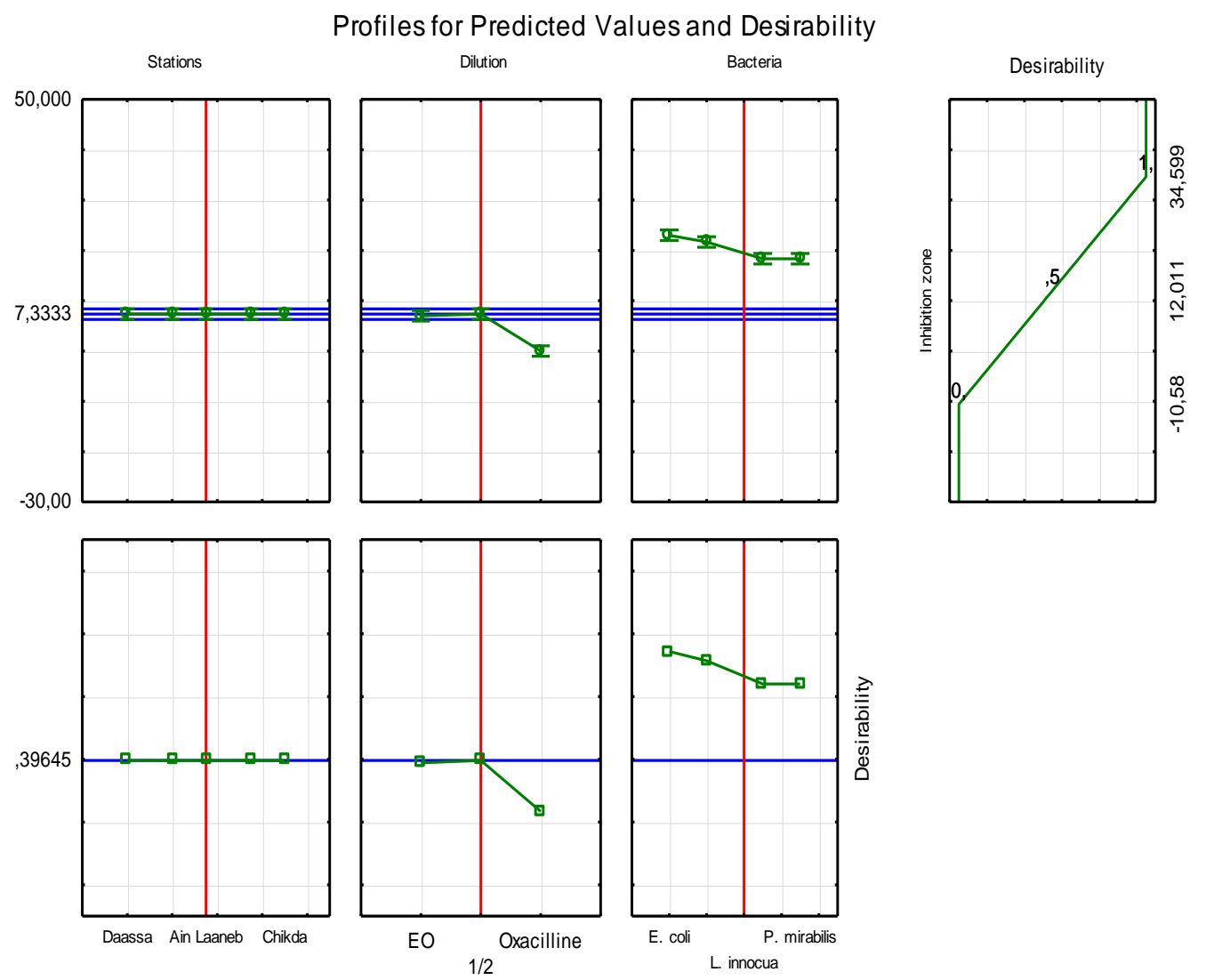

Figure 6. Profile of Predicted Values and Desirability of Pinus halepensis essential oils

We have obtained the same results regarding $P$. aeruginosa and $\mathrm{K}$. pneumoneae strains. However, this study showed that $K$. pneumoneae, and $S$. aureus are resistant. These results are in line with those reported by Abi Ayad et al. (2011) and Mirtic et al. (2019) who observed that $S$. aureus is more sensitive than $E$. coli and $P$. aeruginosa to $P$. halepensis essential oils; this is likely due to difference in bacterial cell membrane structure between the bacteria.

Previous studies showed that S.aureus was sensitive to Pinus helepensis essential oils and suggesting that caryophyllene-E (29.06\% of total oil level) is responsible for the antimicrobial activity against this strain (Dahham et al. (2015) and Mitic et al. (2019). The difference in the inhibition diameters could be mainly due to the difference in the chemical composition of essential oil, while the antibacterial compounds are responsible for inhibiting bacterial multiplication, sporulation, and toxin synthesis (Gachkar et al. 2007; Rasooli et al. 2008). The antibacterial activity of essential oils that are composed of many volatile compounds cannot be confirmed their activity based only on the action of one compound (Bajpai et al. 2012).

The antimicrobial activity of essential oils is related to the presence of antimicrobial compounds. The oxygenated compounds in the essential oils are generally more active than the hydrocarbon molecules, which are known to have weak antimicrobial activity (Kalemba and Kunicka 2003). Antimicrobial activity of essential oil might be acted as synergistic among the compounds in the essential oils (Cao et al. 2009; Bounatirou et al. 2007; Peñalver et al. 2005; Chorianopoulos et al. 2004; Sokmen et al. 2004).

Some studies showed that minor compounds might play a role in the antimicrobial activity (Gill et al. 2002; Rota et al. 2008). Nevertheless, the antibacterial activity of the essential oil in this study might be due to the synergy phenomenon between all the volatile compounds. The synergic interactions between various compounds may affect in more pronounced activity (Al-Bayati, 2008; Randrianarivelo et al. 2009; Hmamouchi et al. 2001; Raut et Karuppayil, 2014). Several studies (Billerbeck et al. 2002; Bouzouta et al. 2008; Xianfei et al. 2007; Sandri et al. 2007; Zarai et al. 2011; Al-Bayati, 2008; Raut et Karuppayil, 2014) reported that Gram positive bacteria are more susceptible to essential oils than Gram negative bacteria. It was reported that the antimicrobial activity of essential oils is strongly related to their hydrophobicity (Dorman et al. 2000; Ultee et al. 2002). The cell walls of Gram positive bacteria are mainly composed of peptidoglycans associated with other molecules, like protein or teichoic acid (Nazaro et al. 2013). The cell walls of Gram negative bacteria possess an outer membrane containing hydrophilic lipopolysaccharides (LPS), as a barrier against hydrophobic compounds, such as those present in essential oils (Nikaido et al. 2003; Pandey et al. 2016). The absence of this barrier in Gram (+) bacteria enables direct contact to hydrophobic compounds of 
essential oil, with the phospholipid bilayer of the cell membrane. It may result in either an increase in the permeability of the ions and the leakage of vital intracellular constituents or deficiency in the enzymatic system (Sandri et al. 2007; Al-Bayati, 2008; Randrianarivelo et al. 2009; Zarai et al. 2011). Moreira et al. (2005) reported that Gram (-) bacteria could be sensible to essential oils.

Generally, the antimicrobial mechanism is due to series of biochemical reactions in the bacterial cells, which are related to the type and characteristics of the chemical compounds in the essential oil (Nazzaro et al. 2013). The potent antimicrobial power of terpenes compounds, and particularly to phenolic terpenes, have been previously investigated by several authors (Van et al. 2006; Sharma et al. 2019). Several studies have shown the relatively lower antimicrobial efficacy of terpene hydrocarbon compounds (Kalemba et al. 2003). The essential oil contained terpene such as $\alpha$-pinene, myrcene, $\beta$-pinene, linalol, myrcene, $\beta$ phellandrene, and germacrene $D$. Terpene have potent antimicrobial activity against Gram-positive bacteria and pathogenic fungi but have weak activity against Gramnegative bacteria (Hada et al. 2003). Jordan et al. (2013) reported that a high proportion of $\alpha$-pinene increases the effectiveness of rosemary essential oils against $S$ aureus. Terpene alcohols are active against microbial cells due to their hydro-solubility, and their ability to induce significant damage to the microorganism cell walls (Dorman et al. 2000; Carson et al. 2002; Hammer et al. 2003). It is similar to the results of this study that the Tafrent population with the highest content of Terpinen-4-ol.

The $\alpha$-terpinene was found to inhibit several bacterial species (Dorman and Deans 2000). In this study, the Bir Ghzala population (Jijel city, northeast Algeria) shows the highest content of $\alpha$-terpinene and active against $E$. coli, $P$. aeruginosa, $K$. pneumonia, S. enterica, B. cereus and $P$. mirabilis. The differences in the efficacy and antibacterial activity could be due to the chemical composition of essential oils, which varies in plant species, geographic region, season, stage, organ and method of extraction (Aprotosoaie et al. 2010).

In conclusion, the essential oils of leaves of $P$. halepensis collected from different altitudes in Eastern Algeria have significantly different yields and chemical composition. There are thirty-seven identified compounds. The main compounds are caryophyllene-E, myrcene, $\alpha$ pinene, phenyl ethyl 3-methyl butanoate, $\alpha$-humulene, terpinolene, and sabinene. Nevertheless, the main compounds of whole oils are common with different percentages following the regions and altitudes. The essential oils collected from different locations have different antibacterial activities.

\section{ACKNOWLEDGEMENTS}

This study was supported financially by MESRS of Algeria (Project code No. D01N01UN190120200005), and no potential conflicts of interest.

\section{REFERENCES}

Abi-Ayad M, Abi-Ayad FZ, Lazzouni HA, Rebiahi SA, Ziani-Cherif C, Bessiere JM. 2011. Chemical composition and antifungal activity of Aleppo pine essential oil. J. Med. Plant Res 5 (22): 5433-5436. http://www.academicjournals.org/JMPR.

Adams RP. 2007. Identification of essential oil components by gas chromatography/ mass spectrometry, 4th Edition. Allured Publ., Carol Stream,

https://www.researchgate.net/deref/http $\% 3 \mathrm{~A} \% 2 \mathrm{~F} \% 2 \mathrm{Fwww}$.juniperus. org $\% 2 \mathrm{~F}$

Al-Bayati AF. 2008. Synergistic antibacterial activity between Thymus vulgaris and Pimpinella anisum essential oils and methanol extracts. Ethnopharmacology 116: 403-406. DOI: 10.1016/j.jep.2007.12.003.

Alonso-Castro AJ, Villarreal ML, Salazar-Olivo LA, Gomez-Sanchez M, Dominguez F, Garcia-Carranca A. 2011. Mexican medicinal plants used for cancer treatment: Pharmacological, phytochemical and ethnobotanical studies. J Ethnopharmacol 133: 945-952. DOI: 10.1016/j.jep.2010.11.055

Amri I, Hamrouni L, Hanana M, Gargouri S, Fezzani T, Jamoussi B. 2013. Chemical composition, physico-chemical properties, antifungal and herbicidal activities of Pinus halepensis Miller essential oils. Biol Agric Hortic 29 (2): 91-106. DOI: 10.1080/01448765.2013.76448

Amri I, Hamrouni L, Hanana M, Jamoussi B, Lebdi K. 2014. Essential oils as biological alternatives to protect date palm (Phoenix dactylifera L.) against Ectomyeloisceratoniae Zeller (Lepidoptera: Pyralidae). Chil J Agric Res 74 (3): 273-279. DOI: 10.4067/s071858392014000300004.

Aprotosoaie AC, Spac AD, Hancianu M, Miron A, Tanasescu VF, Dorneanu V, Stanescu U. 2010. The chemical profile of essential oils obtained from fennel fruits (Foeniculum vulgare Mill.). Farmacia. 58 (1): 46-54. https://www.yumpu.com/en/document/read/43465313/thechemical-profile-of-essential-oils-obtained-from-fennel-fruits

Ashmawy NA, Al Farraj DA, Salem MZM, Elshikh MS, Al-Kufaidy R, Alshammari MK, Salem AZM. 2018. Potential impacts of Pinus halepensis Miller trees as a source of phytochemical compounds: antibacterial activity of the cones essential oil and n-butanol extract. Agroforest Syst. DOI: 10.1007/s10457-018-0324-5

Athanassios Gallis, Carlos Arrabal, Aristotle Papageorgiou, GarciaVallejo MC. 2012. Needle Terpenoid Composition of Pinus halepensis (Mill.) Trees Infested by the Scale Insect Marchalina hellenica (Genn.) in Greece. Proceedings of the $4^{\text {th }}$ International Workshop on Genetics of Host-Parasite Interactions in Forestry. General Technical Report PSW-GTR. 240: 304-308.

Bajpai VK, Baek KH, Kang SC. 2012. Control of Salmonella in foods by using essential oils: are view. Food Res Intl 45: 722-734. DOI: 10.1016/j.foodres.2011.04.052

Berroukche A, Amara S, Halimi S, Benyamina F. 2014. Evaluation of the Leave and Bud Decoctions Pinus halepensis Mill Effects on the Induced-Phenol Renal Toxicity in Wistar Rats. J Fundam Appl Sci 6 (2): 197-207. DOI: 10.4314/jfas.v6i2.6

Bounatirou S, Smiti S, Miguel MG, Faleiro L, Rejeb MN, Neffati M, Costa MM, Figueiredo AC, Barroso JG, Pedro LG. 2007. Chemical composition, antioxidant and antibacterial activities of the essential oils isolated from Tunisian Thymus capitatus Hoff. Et Link Food Chem 105: 146-155. DOI: 10.1016/j.foodchem.2007.03.059

Bouyahya A, Belmehdi O, Abrini J, Dakka N, Bakri Y. 2019. Chemical composition of Mentha suaveolens and Pinus halepensis essential oils and their antibacterial and antioxidant activities. Asian Pac J Trop Med 12: 117-22. doi: 10.4103/1995-7645.254937

Bouzenna H, Samout N, Amani E, Mbarki S, Tlili Z, Rjeibi I, Hfaiedh N. 2016. Protective Effects of Pinus halepensis L. essential oil on aspirin-induced acute liver and kidney damage in female Wistar Albino Rats. J. Oleo Sci 65 (8): 701-712. DOI: 10.5650/jos.ess15287

Cao Li, Jian Yong Si, Yan Liu, Hong Sun, Wen Jin, Zhan Li, Xiao Hong Zhao, Rui Le Pan. 2009. Essential oil composition, antimicrobial and antioxidant properties of Mosla chinensis (Maxim). Food Chem 115 (3): 3801-805. DOI: 10.1016/j.foodchem.2008.12.064

Carson CF, Mee BJ, Riley TV. 2002. Mechanism of action of Melaleuca alternifolia (tea tree) oil on Staphylococcus aureus determined by time-kill, lysis, leakage and salt tolerance assays and electron microscopy. Antimicrob. Agents. Chemother 46: 1914-1920. DOI: 10.1128/aac.46.6.1914-1920.2002 
Catherine Regnault-Roger. 1997. The potential of botanical essential oils for insect pest control. Integr Pest Manag Rev 2 (1): 25-34. DOI: 10.1023/A: 1018472227889

Cheikh-Rouhou S, Hentati B, Besbes S, Blecker C, Deroanne C, Attia H. 2006. Chemical composition and lipid fraction characteristics of Alleppo pine (Pinus halepensis Mill.) seeds cultivated in Tunisia. Food Sci Tech Intl 12 (5): 407-415. DOI: $10.1177 / 1082013206069910$

Chorianopoulos N, Kalpoutzakis E, Aligiannis N, Mitaku S, Nychas GJ, Haroutounian SA. 2004. Essential oils of Satureja, Origanum, and Thymus species: Chemical composition and antibacterial activities against food borne pathogens. J Agric Food Chem 52 (26): 82618267. DOI: $10.1021 / \mathrm{jf0} 49113 \mathrm{i}$

Correal-Mòdol E, Casals MS. 2012. Properties of clear wood and structural timber of Pinus halepensis from northeaster Spain. Proceedings of WCTE Auckland, New Zealand 5: 251-254. https://fr.slideshare.net/incafust/wcte-halepensis-24721903

Dahham SS, Tabana YM, Iqbal MA, Ahamed MBK, Ezzat MO, Majid ASA, Majid AMSA. 2015. The Anticancer, antioxidant and antimicrobial properties of the sesquiterpene $\beta$-caryophyllene from the essential oil of Aquilaria crassna. Molecules 20: 11808-11829. DOI: $10.3390 /$ molecules200711808.

Djerrad Z, Kadik L, Djouahri A. 2015. Chemical variability and antioxidant activities among Pinus halepensis Mill. essential oils provenances, depending on geographic variation and environmental conditions. Ind Crop Prod 74: 440-449. DOI: 10.1002/cbdv.201600340.

Dob T, Berramdane T, Chelghoum C. 2007. Essential oil composition of Pinus halepensis Mill from three different regions of Algeria. J Essent Oil Res 19 (1): 40-43. DOI 10.1080/10412905.2007.9699226

Dob T, Berramdane T, Chelgoum C. 2005. Chemical composition of essential oil of Pinus halepensis Miller growing in Algeria. Comptes Rendus Chimie 8 (11-12): 1939-1945. DOI: 10.1016/j.crci.2005.05.007

Dorman HJD, Deans SG. 2000. Antimicrobial agents from plants: antibacterial activity of plant volatile oils. J Appl Microbiol 88 (2) 308-316. DOI: 10.1046/j.1365-2672.2000.00969.x

Dziri S, Hosni K. 2012. Effects of cement dust on volatile oil constituents and antioxidative metabolism of Aleppo pine (Pinus halepensis) needles. Acta Physiol. Plant. 34 (5): 1669-1678. DOI 10.1007/s11738-012-0962-6

El-Baha AM, El-Settawy AA, Hassan FA, Salem MZ, Soliman MA. 2016 Chemical composition of essential oils extracted from Aleppo pine (Pinus halepensis Mill.) and their termiticidal and fungicidal effects. Alexandria J Agric Sci 61 (3): 193-202.

Fekih N, Allali H, Merghache S, Chaïb F, Merghache D, Amine ME, Djabou N, Muselli A, Tabti B, Costa J. 2014. Chemical composition and antibacterial activity of Pinus halepensis Miller growing in West Northern of Algeria. Asian Pac J Trop Dis 4 (2): 97-103. DOI 10.1016/S2222-1808 (14)60323-6

Gachkar L, Yadegari D, Rezaei MB, Taghizadeh M, Astaneh SA, Rasooli I. 2007. Chemical and biological characteristics of Cuminum cyminum and Rosmarinus officinalis essential oils. Food Chem 102 (3): 898904. DOI: 10.1016/j.foodchem.2006.06.035

Ghalem BR. 2014. Antibacterial potential of essential oils of the needles of Pinus halepensis against Staphylococcus aureus and Escherichia coli. J. Coastal Life Med 2 (8): 651-655. DOI: 10.12980/JCLM.2.2014APJTD-2014-0041.

Gill AO, Delaquis P, Russo P, Holley RA. 2002. Evaluation of ant listerial action of cilantro oil on vacuum packedham. Intl $\mathrm{J}$ Food Microbiol 73 (1): 83-92. DOI: 10.1016/s0168-1605 (01)00712-7.

Hada T, Shiraishi A, Furuse S, Inoue Y, Hamashima H, Masuda K, Shiojima K, Shimada J. 2003. Inhibitory effects of terpene on the growth of Staphylococcus aureus. Nat Med 57: 464-467. DOI: 10.1128/AAC.49.5.1770-1774.2005.

Hammer KA, Carson CF, Riley TV. 2003. Antifungal activity of the components of Melaleuca alternifolia (tea tree) oil. J Appl Microbiol 95 (4): 853-860. DOI: 10.1046/j.1365-2672.2003.02059.x.

Hmamouchi M, Hamamouchi J, Zouhdi M, Bessière JM. 2001. Chemical composition properties of essential oils of five Moroccan Pinaceae. J $\begin{array}{lllll}\text { Essent Oil Res } 13 & \text { (4): 298-302. DOI }\end{array}$ 10.1080/10412905.2001.9699699.

Ioannou E, Koutsaviti A, Tzakou O, Roussis V. 2014. The genus Pinus: a comparative study on the needle essential oil composition of 46 pine species. Phytochem Rev 13 (4): 741-768. DOI: 10.1007/s11101-0149338-4.
Jordán MJ, Lax V, Rota MC, Sotomayor JA. 2013. Effect of bioclimatic area on the essential oil composition and antibacterial activity of Rosmarinus officinalis L. Food Control 30 (2): 463-468. DOI: $10.1177 / 1934578 X 1300800635$.

Kadri N, Khettal B, Adjebli A, Cresteil T, Yahiaoui-Zaidi R, BarraganMontero V, Montero JL. 2014. Anti angiogenic activity of neutral lipids, glycolipids, and phospholipids fractions of Pinus halepensis Mill. seeds. Ind Crop Prod 54: 6-12. DOI: 10.1016/j.indcrop.2013.12.051.

Kalemba D, Kunicka A. 2003. Antibacterial and antifungal properties of essential oils. Curr Med Chem 10: 813-829. DOI: 10.2174/0929867033457719.

Krenaida T, Ilirjan M, Fatos Y, Ramiz M, Adelaida A, Jonilda L. 2018. Spectroscopic study on chemical composition of essential oil and crude extract from Albanian Pinus halepensis Mill. J Agric Infor 9 (1): 41-46. DOI: 10.17700/jai.2018.9.1.440.

Lahlou M. 2003. Composition and molluscicidal properties of essential oils of five Moroccan Pinaceae. Pharm Biol 41 (3): 207-210. DOI:10.1076/phbi.41.3.207.15097.

Macchioni F, Cioni PL, Flamini G, Morelli I, Maccioni S, Ansaldi M. 2003. Chemical composition of essential oils from needles, branches and cones of Pinus pinea, P. halepensis, P. pinaster and P. nigra from central ltaly. Flavour Frag J 18: 139-143. DOI: 10.1002/ffj. 1178

Masada Y. 1976. Analysis of Essential Oils by Gas chromatography and Mass Spectrometry. J. Wiley and Sons, Inc, New York.

Mitić ZS, Jovanović B, Jovanović SČ, Stojanović-Radić ZZ, MihajilovKrstev T, Jovanović NM, Stojanović GS. 2019. Essential oils of Pinus halepensis and $P$. heldreichii: Chemical composition, antimicrobial and insect larvicidal activity. Ind Crop Prod 140: 111702. DOI: 10.1016/j.indcrop.2019.111702.

Mitić ZS, Jovanović B, Jovanović S, Mihajilov-Krstev T, StojanovićRadić ZZ, Cvetković VJ, Mitrović TL, Marin PD, Zlatković BK, Stojanović GS. 2018. Comparative study of the essential oils of four Pinus species: Chemical composition, antimicrobial and insect larvicidal activity. Ind Crop Prod 111: 55-62. DOI: 10.1016/j.indcrop.2017.10.004.

Mohamed G, Badr S, Abdelaziz Ch, Abderrahman A, Abdelhak E, Moulay R, Abdellah F. 2007. Composition chimique et activité antimicrobienne de l'essence de térébenthine du pin maritime (Pinus pinaster) et du pin d'Alep (Pinus halenpensis) du Maroc. Acta Botanica Gallica. 154 (2): 293-300. DOI: 10.1080/12538078.2007.10516058. [France]

Mohareb SA, Kherallah EAI, Badawy EIM, Salem ZMM, Yousef AH. 2017. Chemical composition and activity of bark and leaf extracts of Pinus halepensis and Olea europaea grown in Al-Jabel Al-Akhdar Region, Libya against some plant phytopathogens. J Appl Biotech Bioeng 3 (3): 331-342. DOI: 10.15406/jabb.2017.03.00067.

Montironi ID, Cariddi LN, Reinoso EB. 2016. Evaluation of the antimicrobial efficacy of Minthostachys verticillata essential oil and limonene against Streptococcus uberis strains isolated from bovine mastitis. Rev Argent Microbiol 48: 210-216. DOI: 10.1016/j.ram.2016.04.005

Moreira MR, Ponce AG, de Valle CE, Roura SI. 2005. Inhibitory parameters of essential oils to reduce a food borne pathogen. LWT Food Sci Tech 38: 565-570. DOI: 10.1016/j.1wt.2004.07.012.

Motte-Florac E. 2000. Les utilisations médicinales de la résine de Pin dans le centre du Mexique: la disparition d'un savoir, Acta Botanica Gallica Bot Lett 147 (3): 303-304. DOI: 10.1080/12538078.2000.10515858.

Nam AM, Tomi F, Gibernau M, Casanova J, Bighelli A. 2016 composition and chemical variability of the needle oil from Pinus halepensis growing in Corsica. Chem Biodivers 13: 380-386. DOI: 10.1002/cbdv.201500097.

Nazzaro F, Fratianni F, De Martino L, Coppola R, De Feo V. 2013. Effect of essential oils on pathogenic bacteria. Pharm 6 (12): 14511474. DOI: $10.3390 /$ ph6121451.

Nikaido H. 2003. Molecular basis of bacterial outer membrane permeability revisited. Microbiol Mol Biol Rev 67: 593-656. DOI: 10.1128/ MMBR.67.4.593-656.2003.

NIST. 2002. Mass Spectral Search Program for the NIST/EPA/NIH Mass Spectral Library, vers, 2.0, fiveash data, USA.

Pandey AK, Kumar P, Singh P, Tripathi NN, Bajpai VK. 2016. Essential Oils: Sources of Antimicrobials and Food Preservatives. Front Microbiol 7: 2161. DOI: 10.3389/fmicb.2016.02161 
Quézel P, Marcel B. 1992. Le pin d'Alep et les espèces voisines répartition et caractères écologiques, généraux, sa dynamique récente en France méditerranéenne. Forêt méditerranéenne T. XIII (3): 158-170. [France]

Ponce A G, Fritz R, del Valle C, Roura SI. 2003. Antimicrobial activity of essential oils on the native microflora of organic Swiss chard. LWT Food Sci Tech 36 (7): 679-684. DOI: 10.1016/s0023-6438 (03)00088-4

Randrianarivelo R, Sarter S, Odoux E, Brat P, Lebrun M, Romestand B, Menut C, Andrianoelisoa HS, Raherimandim M, Danthu P. 2009. Composition and antimicrobial activity of essential oils of Cinnamosma fragrans. Food Chem 114: 680-684. DOI: 10.1590/S1517-83822004000300001.

Rasooli I, Fakoor MH, Yadegarinia D, Gachkar L, Allameh A, Rezaei MB. 2008. Antimycotoxigenic characteristics of Rosmarinus officinalis and Trachyspermum copticum L. essential oils. Intl J Food Microbiol 122: 135-139. DOI: 10.1016/j.ijfoodmicro.2007.11.048.

Raut JS, Karuppayil SM. 2014. A status review on the medicinal properties of essential oils. Industrial Crops and Products. 62: 250264. DOI: 10.1016/j.indcrop.2014.05.055.

Rodrigues AM, Mendes MD, Lima AS, Barbosa PM, Ascensão L, Barroso JG, Figueiredo AC. 2016. Pinus halepensis, Pinus pinaster, Pinus pinea and Pinus sylvestris essential oils chemotypes and monoterpene hydrocarbon enantiomers, before and after inoculation with the pine wood nematode Bursaphelenchus xylophilus. Chem Biodiv 14 (1): e1600153. DOI: 10.1002/cbdv.201600153.

Rota MC, Herrera A, Martínez RM, Sotomayor JA, Jordán MJ. 2008. Antimicrobial activity and chemical composition of Thymus vulgaris, Thymus zygis and Thymus hyemalis essential oils. Food Control. 19: 681-687. DOI.org/10.1016/j.foodcont.2007.07.007.

Roussis V, Petrakis PV, Ortiz A, Mazomenos EB. 1995. Volatile constituents of needles of five Pinus species grown in Greece. Phytochem 39 (2): 357-361. DOI: 10.1016/0031-9422 (94)00885-W.

Sandri IG, Zacaria J, Fracaro F, Delamare APL, Echeverrigaray S. 2007. Antimicrobial activity of the essential oils of Brazilian species of the genus Cunila against food borne pathogens and spoiling bacteria, Food Chem. 103: 823-828. DOI: 10.1016/j.foodchem.2006.09.032.

Sharma M, Koul A, Sharma D, Kaul S, Swamy MK, Dhar MK. 2019. Metabolic engineering strategies for enhancing the production of bioactive compounds from medicinal plants. In: Natural Bio-active Compounds. Springer, Singapore. DOI: 10.1007/978-981-13-7438-812.

Simard F. 2007. Evaluation du potentiel anticancéreux des extractibles du bois de pin rouge. Mémoire présenté à l'université du Québec à
Chicoutimi comme exigence partielle de la maîtrise en ressources renouvelables. Universités du Québec, Montreal, Canada. [France]

Sokmen A, Gulluce M, Akpulat HA, Daferera D, Tepe B, Polissiou M, Sokmen M, Sahin F. 2004. The in vitro antimicrobial and antioxidant activities of the essential oils and methanol extracts of endemic Thymus spathulifolius. Food Control 15: 627-634. DOI: 10.1016/j.foodcont.2003.10.005.

Suntar I, Tumen I, Ustun O, Keles H, Akkol E K. 2012. Appraisal on the wound healing and anti-inflammatory activities of the essential oils obtained from the cones and needles of Pinus species by in vivo and in vitro experimental models. J Ethnopharmacol 139: 533-540. DOI: 10.1016/j.jep.2011.11.045.

Tazerouti F, Badjah-Hadj-Ahmed AY, Meklati BY, Favre-Bonvin J, Bobenrieth MJ. 1993. Analyse des huiles essentielles des aiguilles de Pinus halepensis Mill. par CG/SM. Plantes Médicinales et Phytothérapie 26 (3): 161-176. [France]

Tumen I, HafizogluKilic A, Dönmez IE, Sivrikaya H, Reunanen M. 2010. Yields and constituents of essential oil from cones of Pinaceae spp. natively grown in Turkey. Molecules 15: 5797-5806. DOI: $10.3390 /$ molecules15085797

Ultee A, Bennik MHJ, Moezelarr R. 2002. The phenolichydroxyl group of carvacrolis essential for action against the food-borne pathogen Bacillus cereus. Appl Environ Microbiol 68: 1561-1568. DOI: 10.1128/AEM.68.4.1561-1568.

Ustun O, Sezik E, Kurkcuoglu M, Baser KHC. 2006. Study of the essential oil composition of Pinus sylvestris from Turkey. Chem Nat Comp 42: 26-31. DOI: 10.1007/s10600-006-0029-2.

Van Zyl RL, Seatlholo ST, Van Vuuren SF, Viljoen AM. 2006. The biological activity of 20 nature identical essential oil constituents. J Essent Oil Res 18: 129-133. DOI: 10.1080/10412905.2006.12067134

Vekiari SA, Protopapadakis EE, Papadopoulou P, Papanicolaou D, Panou C, Vamvakias M. 2002. Composition and seasonal variation of the essential oil from leaves and peel of a cretan lemon variety. J Agric Food Chem 50 (1): 147-153. DOI: 10.1021/jf001369a.

Vidrich V, Michelozzi M, Fusi P, Heimler D. 1988. Essential oils of vegetables species of the mediterranean and alpine temperate climate areas. $4^{\text {th }}$ E.C. Conference, Biomass for Energy and Industry.

Zarai Z, Kadri A, Ben Chobba I, Ben Mansour R, Bekir A, Mejdoub A, Gharsallah N. 2011. The in-vitro evaluation of antibacterial, antifungal and cytotoxic properties of Marrubium vulgare L. essential oil grown in Tunisia. Lipids Health Dis 10: 161. DOI: 10.1186/1476$511 \mathrm{X}-10-161$ 
Table S1. Chemical composition of Pinus halepensis essential oils from various countries

\begin{tabular}{|c|c|c|c|c|c|c|c|c|c|c|c|c|c|c|c|c|c|c|c|c|c|c|}
\hline Localities & 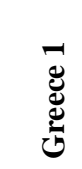 & 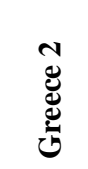 & 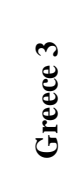 & 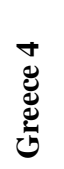 & 䔍 & 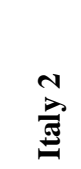 & 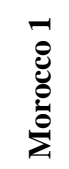 & 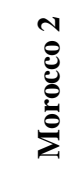 & 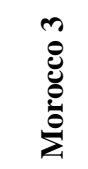 & 胥 & 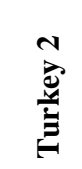 & 晃 & 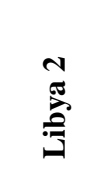 & $\stackrel{n}{\stackrel{n}{3}}$ & $\begin{array}{l}\overrightarrow{0} \\
\ddot{0} \\
\dot{0}\end{array}$ & 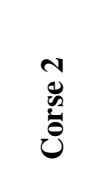 & 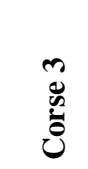 & $\underset{\overrightarrow{0}}{\overrightarrow{0} 0}$ & 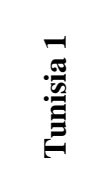 & 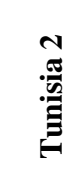 & 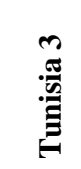 & : \\
\hline Authors* & $\mathbf{A}$ & B & $\mathrm{C}$ & D & $\mathbf{E}$ & $\mathbf{F}$ & $\mathbf{G}$ & $\mathbf{H}$ & I & $\mathbf{J}$ & $\mathbf{K}$ & & $\mathbf{L}$ & & & $\mathbf{M}$ & & $\mathbf{N}$ & $\mathbf{O}$ & $\mathbf{P}$ & $\mathbf{Q}$ & $\mathbf{R}$ \\
\hline$\alpha$-pinene & 5.3 & 13.4 & 8 & 3.4 & 18 & 8.5 & 23 & 23 & 12 & 18 & 47 & 14 & 7.3 & 3.7 & 9.8 & 22 & 13 & 10 & 9.9 & 13 & 10 & 39 \\
\hline Sabinene & 2.4 & 1.3 & 1.7 & 0.4 & 9.4 & 6.1 & 3.7 & 3.7 & 0.7 & 0.1 & 0 & 0 & 0 & 0 & 0.7 & 0.4 & 6.4 & 0 & 1.1 & 1.2 & 6.4 & 0 \\
\hline$\beta$-pinene & 0.8 & 1.1 & 1.9 & 0.3 & 2 & 1.1 & 3.1 & 3.1 & 0 & 47 & 2.8 & 20 & 7.9 & 1.1 & 0.8 & 1.6 & 1.7 & 0 & 10.7 & 5.1 & 12 & 2.3 \\
\hline Myrcene & 4.9 & 6.6 & 15 & 5.2 & 28 & 13 & 16 & 16 & 24 & 1.3 & 6.3 & 3.8 & 2 & 0.8 & 4.3 & 3.5 & 39 & 0 & 9.5 & 21 & 0 & 17 \\
\hline$\Delta 3$-Carene & 0.3 & 6.9 & 0.5 & 1.1 & 1.7 & 0.9 & 0 & 0 & 0 & 0.9 & 1.7 & 1.9 & 0.4 & 2.8 & 0.4 & 2.1 & 1.5 & 7.6 & 0.8 & 1 & 0.8 & 17 \\
\hline p-cymen & 0 & 0 & 0 & 0 & 1.1 & 11 & 0.7 & 0.7 & 0.7 & 0 & 0.4 & 0 & 0 & 0 & 0.2 & 0.3 & 0.2 & 0 & 1.2 & 0.3 & 0.8 & 0 \\
\hline Limonene & 0.5 & 5 & 1 & 0 & 1.1 & 1 & 1.3 & 1.3 & 1 & 2.3 & 0.8 & 0 & 0 & 0 & 0.4 & 0.8 & 0.9 & 0 & 1.9 & 1.6 & 0.6 & 0 \\
\hline Terpinolène & 2.5 & 3.1 & 1.9 & 1 & 0 & 0 & 10 & 10 & 1.3 & 0.3 & 0 & 1.4 & 1.8 & 1.9 & 1.1 & 2.8 & 7.3 & 0 & 0 & 0 & 0 & 0 \\
\hline$\alpha$-terpinolene & 0 & 3.1 & 0 & 0 & 9.9 & 0 & 0 & 0 & 0 & 0 & 0.1 & 0 & 0 & 0 & 0 & 0 & 0 & 0 & 5.4 & 6.7 & 0 & 0 \\
\hline Terpinen-4-ol & 0.1 & 0.7 & 0.2 & 0.3 & 0 & 0 & 3.8 & 3.8 & 0 & 0 & 0 & 0.4 & 2.3 & 1.8 & 0.3 & 0.9 & 1.1 & 0 & 0.2 & 0.6 & 0.1 & 0 \\
\hline$\alpha$-terpineol & 0 & 0.5 & 0 & 0.1 & 0.2 & 0 & 0.6 & 0.6 & 1.3 & 0.8 & 0.3 & 1 & 11 & 2 & 0.1 & 0.3 & 0.2 & 0 & 0.1 & 0.3 & 0 & 0 \\
\hline Geranyl acetate & 0 & 0.2 & 0 & 0 & 0.3 & 0.9 & 5.3 & 0 & 0 & 0 & 0 & 0 & 0 & 0 & 0.1 & 1.3 & 0.5 & 0 & 0 & 0 & 0 & 0 \\
\hline$\beta$-caryophyllene & 12 & 19 & 19 & 32 & 16 & 26 & 14 & 14 & 28 & 9.2 & 11 & 8.5 & 25 & 27 & 50 & 31 & 16 & 41 & 0 & 0 & 0.1 & 6.3 \\
\hline$\alpha$-humullene & 2 & 3.4 & 3.8 & 5.9 & 2.9 & 0 & 3.2 & 3.2 & 2.8 & 1.8 & 2.7 & 0 & 0 & 0 & 8 & 5 & 2.7 & 0 & 5.2 & 2.6 & 15 & 0 \\
\hline Germacrene-D & 1.2 & 0.5 & 0 & 1 & 0.1 & 0 & 0 & 0 & 0.74 & 8.8 & 0 & 8.4 & 0.6 & 1.5 & 0.2 & 0.4 & 0.9 & 0 & 0 & 0 & 0.5 & 0 \\
\hline Methyl isoeugenol & 0 & 0 & 0 & 0 & 0 & 5.1 & 0 & 0 & 0 & 0 & 0 & 0 & 0 & 0 & 0 & 0 & 0 & 0 & 0 & 0 & 0 & 0 \\
\hline Phenyl ethylisovalerate & 4 & 0 & 0 & 0 & 0 & 0 & 0 & 0 & 0 & 0 & 0 & 1 & 7.6 & 8 & 2.7 & 5.7 & 3.3 & 0 & 0 & 0 & 0 & 0 \\
\hline Caryophyllene oxide & 0 & 0 & 0.3 & 0.8 & 0.1 & 0 & 1.2 & 1.2 & 6.8 & 0.4 & 7.5 & 1.3 & 1.4 & 1.9 & 3.1 & 1.6 & 0.7 & 1.8 & 0 & 0.4 & 0.9 & 0 \\
\hline$\alpha$-cadinol & 0 & 0 & 0 & 0 & 0 & 0 & 0 & 0 & 0 & 0 & 0 & 1.5 & 1.4 & 1.9 & 0 & 0 & 0 & 0 & 0 & 6.1 & 0 & 0 \\
\hline Cembrene & 33 & 7.6 & 6.5 & 2.2 & 0 & 0 & 0 & 0 & 0 & 0 & 0 & 0 & 0 & 3.9 & 0.6 & 2.5 & 0 & 0 & 0 & 0 & 0 & 0 \\
\hline Thumbergol & 0 & 0 & 0 & 29 & 0 & 0 & 0 & 0 & 0 & 0 & 0 & 0 & 0 & 6.2 & 0 & 0 & 0 & 4 & 0 & 0 & 0 & 0 \\
\hline$\beta$-elmene & 0 & 0 & 0 & 0 & 0 & 0 & 0 & 0 & 0 & 0 & 0 & 0 & 0 & 0 & 0 & 0 & 0 & 0 & 0 & 0 & 22 & 0 \\
\hline Longifolene & 0 & 0 & 0 & 0 & 0 & 0 & 0 & 0 & 0 & 0 & 0 & 0 & 0 & 0 & 0 & 0 & 0 & 0 & 34 & 0 & 0 & 0 \\
\hline
\end{tabular}

Note: *) A- Gallis et al. (2012); B- Roussis et al (1995); C- Efestathia et al (2014); D- Mitić et al. (2019). E- Macchioni et al. (2003); F- Vidrich et al (1988); G- Hmamouchi et al. (2001); HLahlou (2003); I- Bouyahya et al. (2019); J- Ustun et al. (2012); K- Tumen et al. (2010); L- Mohareb et al. (2017); M- Nam et al. (2016); N- El-Baha et al. (2016); O- Amri et al. (2013); P- Amri et al. (2014); Q- Dziri and Hosni 2012; R- Rodrigues et al (2017). 
Table S2. Chemical composition of Pinus halepensis essential oils from Algeria

\begin{tabular}{|c|c|c|c|c|c|c|c|c|c|c|c|c|c|c|c|c|c|c|}
\hline Localities & 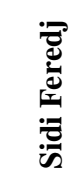 & 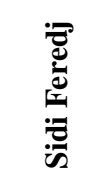 & 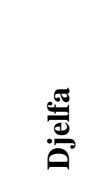 & 䞤 & 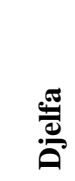 & 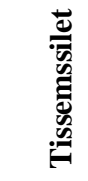 & $\frac{\sqrt[\sigma]{\sigma}}{\stackrel{⿹}{\sigma}}$ & 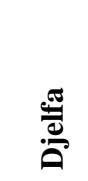 & 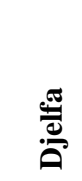 & 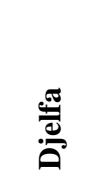 & 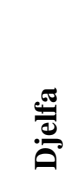 & & 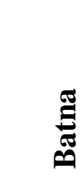 & & & 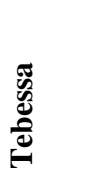 & 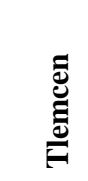 & 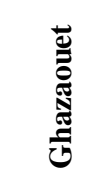 \\
\hline Authors** & $\mathbf{A}$ & & B & & & $\mathrm{C}$ & & & D & & & & $\mathbf{E}$ & & & $\mathbf{F}$ & $\mathbf{G}$ & $\mathbf{H}$ \\
\hline$\alpha$-pinene & 1.2 & 0.7 & 5.2 & 6.4 & 18 & 6.7 & 12 & 12 & 11 & 11 & 14 & 8.5 & 7.6 & 17 & 21 & 22 & 12 & 0 \\
\hline Sabinene & 1.2 & 0.1 & 0.8 & 0.7 & 3 & 7 & 1.5 & 0.1 & 0 & 0 & 0 & 1.5 & 0 & 0.9 & 1.2 & 1.8 & 4.2 & 0 \\
\hline$\beta$-pinene & 0.2 & 1 & 5 & 5.6 & 2 & 2 & 0.6 & 0.5 & 0.9 & 0.2 & 0.6 & 1.7 & 1.9 & 0.6 & 3.1 & 1.6 & 1.9 & 0 \\
\hline Myrcene & 3.1 & 0.3 & 0.2 & 0.5 & 3 & 8.7 & 24 & 22 & 22 & 20 & 22 & 17 & 17 & 11 & 13 & 14 & 25 & 0 \\
\hline$\Delta 3$-carene & 0.2 & 0.2 & 0 & 0.4 & 0 & 0.1 & 0.4 & 0.9 & 0.8 & 0.8 & 2.6 & 1.9 & 2.7 & 0 & 1.3 & 1.3 & 1.6 & 0 \\
\hline p-cymen & 0 & 0 & 0 & 0 & 3 & 0.3 & 11 & 11 & 11 & 12 & 11 & 15 & 14 & 10 & 9.7 & 9.3 & 0.6 & 0.6 \\
\hline Limonene & 0 & 0.1 & 0.1 & 0.1 & 0 & 0.8 & 0.5 & 0.5 & 0 & 0.6 & 0.6 & 1.4 & 3.1 & 2.7 & 0.8 & 1.3 & 0.9 & 0 \\
\hline$\beta$-ocimene cis & 0 & 0 & 0 & 0 & 0 & 0 & 0 & 0.7 & 0.9 & 0.5 & 0 & 2.5 & 2.7 & 1.4 & 0 & 1 & 0.4 & 0 \\
\hline$\beta$-ocimene trans & 0.2 & 0.1 & 1.3 & 1.2 & 0 & 2 & 0 & 0.9 & 2.3 & 0.4 & 0 & 3.6 & 4.2 & 1.7 & 0 & 1.5 & 1.4 & 0 \\
\hline$\gamma$-terpinene & 0 & 0 & 0.3 & 0.3 & 0 & 1 & 1.1 & 0.2 & 0.8 & 0.2 & 0.5 & 0.6 & 0.4 & 1.5 & 0.9 & 1.3 & 1.4 & 0 \\
\hline Terpinolene & 0 & 0.8 & 0.1 & 2.4 & 0 & 0 & 0 & 1 & 0 & 0.1 & 0 & 5.8 & 2.3 & 4.6 & 0 & 1.1 & 8.3 & 0 \\
\hline$\alpha$-terpinolene & 0.1 & 0 & 0 & 0 & 0 & 0.2 & 0 & 0 & 0 & 1 & 1 & 0 & 0 & 0 & 0 & 0 & 0 & 0 \\
\hline Linalool & 0 & 0.1 & 0 & 0 & 2 & 0 & 0 & 0 & 0.9 & 0 & 0 & 0 & 0 & 1.2 & 1.3 & 0.8 & 0.4 & 0 \\
\hline Terpinen-4-ol & 0 & 0.1 & 0 & 0.6 & 1 & 0 & 0 & 0.4 & 0.9 & 0.1 & 0.9 & 3.4 & 1.5 & 1.5 & 0 & 0 & 4.2 & 0.3 \\
\hline$\beta$-caryophyllene Z & 40 & 20 & 26 & 25 & 0 & 0 & 26 & 26 & 24 & 25 & 24 & 16 & 17 & 20 & 23 & 21 & 0 & 0 \\
\hline$\beta$-caryophyllene-E & 0 & 0 & 0 & 0 & 3 & 7.1 & 0 & 0 & 0.7 & 0.7 & 0.1 & 0 & 0.5 & 1.8 & 1.2 & 1.4 & 11 & 0 \\
\hline Aromadendrene & 7.1 & 7 & 0 & 5 & 0 & 0 & 0.4 & 0.3 & 0.7 & 0.4 & 0.9 & 1.2 & 1.6 & 1.5 & 0 & 0.9 & 0 & 0 \\
\hline$\alpha$-humullene & 7.9 & 6.2 & 0.6 & 11 & 1 & 2.8 & 0.7 & 5 & 0.2 & 0.6 & 0.8 & 1.9 & 1.5 & 0.8 & 1.2 & 1.7 & 2.1 & 3.7 \\
\hline Germacrene D & 0.5 & 0.1 & 2.2 & 0.8 & 0 & 0.2 & 0.3 & 0.5 & 0.6 & 0.7 & 0.9 & 2.9 & 1.4 & 1.8 & 1.9 & 1.4 & 0.1 & 0 \\
\hline Phenyl ethyl 2-methylbutyrate & 0 & 0 & 0 & 0 & 10 & 1 & 0 & 0 & 0 & 0 & 0 & 0 & 0 & 0 & 0 & 0 & 0 & 0 \\
\hline Phenyl ethyl-isovalerate & 0 & 0 & 0 & 0 & 8 & 7.4 & 0 & 0 & 0 & 0 & 0 & 0 & 0 & 0 & 0 & 0 & 0 & 5.8 \\
\hline Caryophyllene oxide & 0 & 0 & 0 & 0 & 0 & 0 & 12 & 13 & 11 & 12 & 11 & 0 & 0 & 0 & 0 & 0 & 0.8 & 48 \\
\hline Thumbergol & 0 & 0 & 0 & 0 & 0 & 0 & 0 & 0 & 0 & 0 & 0 & 0 & 0 & 0 & 0 & 0 & 0 & 8.3 \\
\hline
\end{tabular}

Note: **) A. Dob et al. (2005); B. Dob et al. (2007); C. Tazerouti et al. (1993); D. Djerrad et al. (2015); E. Djerrad et al. (2015); F. Djerrad et al. (2015); G. Fekih et al. (2014); H. Abi ayed et al. (2011). 